\title{
Evaluation of Assessment Method to Incorporate Graduate Attributes in Building Surveying Module
}

\section{SANDEEP CHOWDHRY ${ }^{1}$, CELINE GARNIER ${ }^{2}$}

${ }^{1}$ Lecturer, School of Engineering, Edinburgh Napier University, Scotland, U.K. ${ }^{2}$ Lecturer, School of Engineering, Edinburgh Napier University, Scotland, U.K. Email: s.chowdhry@napier.ac.uk, c.garnier@napier.ac.uk

Published Online: December 28, 2016

The Author(s) 2016. This article is published with open access at www.chitkara.edu.in/publications

\begin{abstract}
This study aims at finding out whether an alternate assessment strategy in Sustainable Developments module to improve the student's employability skills and qualities. The exploratory studies, quantitative and qualitative questions acted as a data gathering instruments. The findings showed a need to change the current assessment strategy for Sustainable Developments module, proposed a new assessment approach and evaluated it. The research infers the studied institution should encourage academic staff to get familiar with the effective learning strategies, students learning styles and how to assess an assessment plan with graduate attributes model. A suggested direction for further research is to create an assessment model based on the students learning styles, assessment strategies and the workload information.
\end{abstract}

Keywords: Graduate Attributes, Problem-Based Learning, Assessment Strategy, Employability Skills, Assessment Evaluation.

\section{INTRODUCTION}

In 2009, following the suggestions from the Quality Assurance Agency (QAA), Edinburgh Napier University (ENU) developed a graduate attributes model to inculcate professionalism among the students and to fulfil the needs of the employers (Edinburgh Napier University, 2009). The four essential dimensions of the ENU graduates are, 1) Application of \& contribution to the knowledge, 2) Learning for life, 3) World of work prepared, 4) Citizenship. Considering the Validity, Reliability, Practicality, Cost-effectiveness, Fairness and Usefulness (V.R.P.C.F.U.) criteria (Brown and Knight,1994), the current assessment scheme in the module Sustainable Developments (BSV 10104), does not test generic skills that students have developed over the course of their studies. Therefore, providing various assessments might improve the graduate attributes through building their confidence and increase employability. This study will thus, evaluate the Sustainable Development module taught in the
Journal on Today's Ideas Tomorrow's Technologies, Vol. 4, No. 2, December 2016 pp. $118-171$

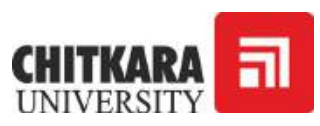


$4^{\text {th }}$ year at ENU. It is a compulsory module for students studying on various built environment courses. The module is testing conceptual and disciplinary knowledge through a written, three-hour and essay-type examination. Although this method of assessment has advantages when dealing with large cohorts and managing tutor's workloads, it does not teach effectively the application of knowledge which an alternate or another form of assessment might provide. Additionally, solely this method of assessment may create tension with the validity and fairness of the assessment potentially creating inequality within the whole student cohort which is against Edinburgh Napier University strategic aims.

The study seeks to find out the possibility of using an alternative assessment strategy within the BSV10104 module, to improve the student's learning experience, employability skills and attributes. The study objectives are 1) to appraise the reasons influencing assessment strategies. 2) to identify assessment strategies available for improved learning in a large cohort, 3) to evaluate current assessment practice and develop new methods of assessment within the BSV10104 module, 4) identify the area of development, 5) assess how the new proposed evaluation strategy could improve graduate employability skills and attributes.

\section{RESEARCH DESIGN}

A review of relevant literature will help in evaluating methods of assessment available and their implementation in a large cohort. It will assist in identifying possible changes needed in the Learning, Teaching and Assessment (LTA) strategy of the module under study. An evaluation of the BSV10104 module will comprise of critiquing the current LTA approach, and the student's feedback received through the survey questionnaires. The assessment of the "V.R.P.C.F.U." criteria of the assessment scheme and the analysis of each activity's cognitive level will help in the evaluation. Questionnaires will appraise the degree to the students' satisfaction and students' attributes developed by the module. These will contribute to identifying needed improvements to the module. Finally, the Higher Education Academy (HEA) (2011) "Assessment Audit Tool", "Employability Audit Tool" and Edinburgh Napier University's "Module Evaluation Checklist" will help in self-evaluation of the current BSV10104 assessment strategy. Bloom's cognitive levels, students' employability skills and attributes, as well as the assessment for learning and V.R.P.C.F.U. Criteria will help in evaluating the proposed new assessment scheme. The same audit tools and evaluation checklist mentioned above will assist in the self-evaluation of the new draft assessment strategy. The exploratory and descriptive analysis will help in identifying the trends in this research.
Evaluation of

Assessment

Method to

Incorporate

Graduate Attributes in Building Surveying Module

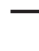




\section{Chowdhry, S. LITERATURE REVIEW}

Crossling \& Webb (2002) outlined the increase in diversity of the Higher Education student population over recent years such as (1) race/ethnicity (2) disability, (3) gender, (4) age (traditional or returning students), (5) socioeconomic status, (6) residential status (campus residents), (7) sexual orientation, (8) religion/belief, (9) national citizenship (domestic or international students), (10) learning styles, (11) mode of attendance Part Time/ Full Time, (12) educational background and experiences, (13) personality profile (Edinburgh Napier University, 2012a; Benzies, 2011; Cuseo, 1992). It is important to consider the above aspects when planning the curriculum to ensure no different levels of knowledge and skills occur between distinct groups of students and to meet the diverse needs of all students. (Cuseo, 1992).

Previous research (Biggs and Tang, 2007) outline the intrinsic link between students' learning approaches with students' achievement of learning outcomes. Teaching and Assessment Methods significantly affect students' approaches to learning. Although students are likely to have a varied approach to learning integrating ideas of both surface and strategic or deep \& strategic approaches, teaching and assessment methods need to adapt to students need and diversity(Rodriguez and Francisco Cano, 2007). Biggs and Tang(2007) studies have outlined that constructively aligned courses encourage students to adopt a deep learning approach and increase students' level of cognitive learning.

Assessing a large student cohort with a diverse mix of students with different needs significantly increase marking and feedback workloads for staff and is challenging to keep consistency and reliability in marks. University of Reading (2013) studies suggests different assessment strategies in finding efficient ways to assess students and provide them with effective feedback supporting their learning such as 1) Clarification of criteria strategy, 2) Do it in class, 3) Self and Peer Assessment, 4) Group assessment, 5) Mechanise the assessment, 6) Interactive online discussions, 7) Strategic reduction.

Kolb (1984) considers learning as a cyclical process progressing from the actual learning experience through case-studies, to the reflection through lectures and tests, to the conceptualisation and active experimentation through reading, projects, and discussions. Additionally, previous research suggests that assessment is the centre of the student learning experience and the assessment's demand, and quality control the students' engagement in learning (Brown and Knight, 1994). Efficient use of the assessment can also promote learning, engagement and higher cognitive competencies through students gaining an insight into their progress and skills (Harrison and Black, 2004). 
Struyven, Dochy and Janssens (2005) outline five most important aspects of assessment in improving the student experience. It should be 1) related to authentic tasks, 2) be reasonable in demand, 3) support the application of knowledge within real contexts, 4) encourage competence development, and 5) demonstrate long-term benefits.

Various authors outline practices to align higher education with long learning through sustainable, learning orientated assessment (formative or summative) providing students with the ability to meet their future learning needs (Boud, 2000). They highlight the need for students to become assessors within the context of participation in practice, thus reproducing learning faced in life and work. This approach is in alignment with the Edinburgh Napier University LTA strategy aimed at developing self-confidence, ability and attributes of students to make them highly employable (ENU, 2011a). Edinburgh Napier University's employability skills and attributes as shown in Figure 1 below.

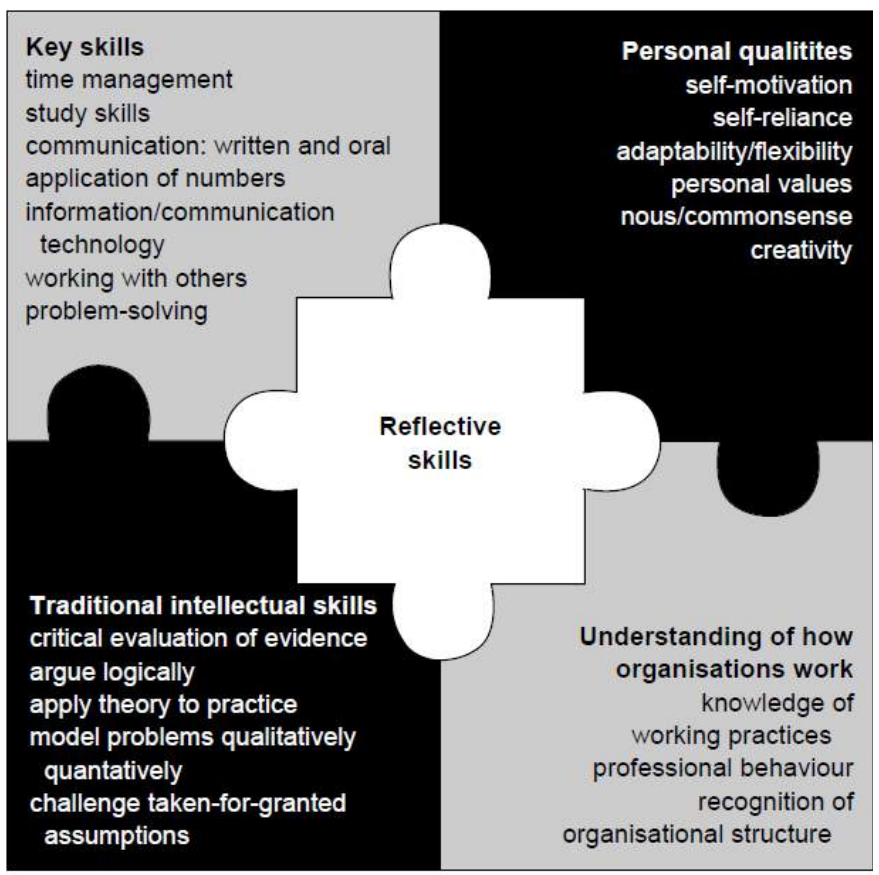

\begin{tabular}{|c|}
\hline $\begin{array}{c}\text { Reflective skills } \\
\text { learning to learn }\end{array}$ \\
identification of own strengths and development needs \\
continuously improving one's own performance
\end{tabular}

Figure 1: Student employability skills and attributes

(Source: Edinburgh Napier University, 2011a)
Evaluation of

Assessment

Method to

Incorporate

Graduate Attributes

in Building

Surveying Module 
Chowdhry, S. Garnier, C.
Selecting a suitable assessment strategy to support the learning outcomes (LOs) (see Appendix I) of the curriculum is essential to improve the students' experience while also developing general skills and abilities within disciplinary contexts (Crooks, 1988). There are different types of assessment coexisting within Higher Education from summative to formative assessment. Providing productive and efficient feedback on specific assessments is essential to improve the student learning, development, and teaching experience. Keppell and Carless (2006) outline how student learning is likely to improve by using various assessment tasks within a module, thus supporting different ways of learning. The combination of series of evaluations works and by viewing it as an integral unit of teaching and learning can help in the development of an effective assessment practice. However, previous research also outlines that if a student can manage an individual assessment on its own, the set of tasks as a whole can be too demanding for them, and they may become very selective in the tasks they focus on (Lindberg-Sand and Olsson, 2008). Indeed, Struyven, Dochy and Janssens (2005) suggest that although students feel alternative assessments as better methods to achieve deep learning, heavy workloads would hinder real studying and thus deep learning (Chambers, 1992). The evaluation scheme must, therefore, consider the five key criteria of Validity, Reliability, Practicality, Cost-effectiveness, Fairness and Usefulness to ensure it is suitable and aligned with module contents and teaching methods (Brown and Knight, 1994; Freeman and Lewis, 1998). Additionally, previous modules evaluation showed that Biggs' model of constructive alignment is essential to allow the learner to improve and achieve independence. Meaningful development of the learning activities and assessments need in alignment to LOs to ensure a good experience (Biggs, 1999). LTA strategy is the means of delivering the module aims through linking learning, teaching, and assessment. The alignment between learning activities, teaching and assessment procedures needs a continuous evaluation from student's feedback and interaction between involved parties, needs to be addressed in this study (Teixeira-Dias et al., 2005).

Assessment for Learning (AfL) also referred as "alternative assessment". It is an evaluation environment that "is rich informal feedback (tutor \& self-assessment systems), is rich in informal feedback (dialogue \& peerinteraction), provide opportunities to try out and practice knowledge, skills and understanding, has assessment tasks which are authentic or relevant. It helps students to develop independence and autonomy and has an appropriate balance between formative and summative assessment" (McDowell et al., 2011, p.750).

Problem-Based Learning (PBL) is a "learning environment where the problem drives the learning" (Klegeris and Hurren, 2011). Pedrosa de Jesus and Coelho Moreira (2009) outlined the deep engagement of students within formative and summative problem-based cases, supporting the use of these alternative assessment tools for lifelong learning skills 
development. This learning technique has also shown to increase student's experience with a high student satisfaction and to promote employability skills and attributes (Kelgeris and Hurren, 2011). Wood (2003) describes PBL in seven steps such as 1) situation and terminology clarification, 2) problem identification, 3) suggestions of possible causes/hypothesis, 4) the connection of problems and causes, 5) a decision on information collection needed 6) obtain information, 7) apply information. While PBL's extensive use in small group settings and showed significant benefits such as improving problem-solving skills, retention of information, increasing students motivation and participation. PBL has application in a large student cohort by combining a PBL tutor less groups approach with standard lectures (Klegeris and Hurren, 2011).

\section{Evaluation of the current module LTA Strategy}

Using the BSV10104 Module Descriptor, a general assessment of the LTA strategy helped in identifying the constructive alignment of the learning outcomes (LOs) and evaluation method.

Table 1: Relationship between LOs, Bloom's cognitive domain and SMART system

\begin{tabular}{|l|l|l|l|l|l|l|}
\hline \multirow{2}{*}{ LOs } & \multicolumn{3}{l|}{ SMART } & \multicolumn{2}{l|}{ BLOOM } \\
\hline & S* & M* & A* & R* & T* & Cognitive \\
\hline $\begin{array}{l}\text { LO1: interpret and analyse environ- } \\
\text { mental policy at global and local levels }\end{array}$ & $\checkmark$ & $\checkmark$ & $\checkmark$ & $\checkmark$ & $\checkmark$ & $\checkmark$ \\
\hline $\begin{array}{l}\text { LO2: explain and evaluate the prin- } \\
\text { ciples of environmental issues in the } \\
\text { development life cycle }\end{array}$ & $\checkmark$ & $\checkmark$ & $\checkmark$ & $\checkmark$ & $\checkmark$ & $\begin{array}{l}\checkmark \\
\text { C, E** }\end{array}$ \\
\hline $\begin{array}{l}\text { LO3: evaluate, propose and justify the } \\
\text { choices available for components in the } \\
\text { development of buildings }\end{array}$ & $\times$ & $\checkmark$ & $\checkmark$ & $\checkmark$ & $\checkmark$ & $\begin{array}{l}\checkmark \\
\text { An, S, } \\
\text { E** }\end{array}$ \\
\hline $\begin{array}{l}\text { LO4: assess the legislative factors } \\
\text { affecting environmental planning and } \\
\text { sustainable development }\end{array}$ & $\times$ & $\checkmark$ & $\checkmark$ & $\checkmark$ & $\checkmark$ & $\begin{array}{l}\checkmark \\
\text { E** }\end{array}$ \\
\hline $\begin{array}{l}\text { LO5: assess environmental impact of } \\
\text { developments on the environment }\end{array}$ & $\times$ & $\checkmark$ & $\checkmark$ & $\checkmark$ & $\checkmark$ & $\begin{array}{l}\checkmark \\
\text { E** }\end{array}$ \\
\hline $\begin{array}{l}\text { LO6: evaluate developments in local } \\
\text { energy and environmental planning }\end{array}$ & $\times$ & $\checkmark$ & $\checkmark$ & $\checkmark$ & $\checkmark$ & $\begin{array}{l}\checkmark \\
\text { E** }\end{array}$ \\
\hline
\end{tabular}

*S.M.A.R.T.: Specific, Measurable, Achievable, Relevant and Time-restricted

**K.C.Ap.An.S.E.: Knowledge, Comprehension, Application, Analysis, Synthesis, Evaluation.
Evaluation of

Assessment

Method to

Incorporate

Graduate Attributes

in Building

Surveying Module 
Chowdhry, S. Garnier, C.

Table 2: Current LTA strategy against Bloom's cognitive domain

\begin{tabular}{|l|l|l|l|l|l|l|}
\hline & \multicolumn{6}{|l|}{ Bloom's cognitive domain } \\
\hline Assessment Scheme & K * & C * & Ap * & An* & S* & E* \\
\hline Exam & $\checkmark$ & $\checkmark$ & - & $\checkmark$ & $\checkmark$ & $\checkmark$ \\
\hline Non-assessed activities & \multicolumn{7}{|l|}{$\mid$} \\
\hline Research Activities & $\checkmark$ & $\checkmark$ & - & - & - & - \\
\hline Reflection Activities & - & - & $\checkmark$ & $\checkmark$ & $\checkmark$ & $\checkmark$ \\
\hline Discussions & & & & & $\checkmark$ & $\checkmark$ \\
\hline
\end{tabular}

*K.C.Ap.An.S.E.: Knowledge, Comprehension, Application, Analysis, Synthesis, Evaluation.

Table 3: Current LTA strategy against employability skills and attributes

\begin{tabular}{|l|l|l|l|l|l|l|l|l|}
\hline & \multicolumn{6}{|l|}{ Employability skills and attributes } \\
\hline Assessment Scheme & P* & Co* & Cr* & I* & D* & T* & M* & N* \\
\hline Exam & $\checkmark$ & - & $\checkmark$ & $\checkmark$ & - & - & $\checkmark$ & $\checkmark$ \\
\hline Non-assessed activities & \multicolumn{7}{|l|}{} \\
\hline Research Activities & - & - & - & $\checkmark$ & - & - & $\checkmark$ & $\checkmark$ \\
\hline Reflection Activities & $\checkmark$ & - & $\checkmark$ & $\checkmark$ & $\checkmark$ & - & $\checkmark$ & $\checkmark$ \\
\hline Discussions & - & $\checkmark$ & $\checkmark$ & - & - & $\checkmark$ & $\checkmark$ & $\checkmark$ \\
\hline
\end{tabular}

* P, Co, Cr, I, D, T, M, N: Problem formulation and solving, communication and cooperation, critical and creative thinking, independent learner, decision-making, teamwork and group leadership, management of time and resources; and numeracy and intellectual skills.

Table 4: Current LTA strategy against assessment for learning (Afl) environment criteria

\begin{tabular}{|l|l|l|l|l|l|l|}
\hline & \multicolumn{7}{|c|}{ Afl Environment Criteria } \\
\hline Assessment Scheme & FF* & IF* & P* & R* & Di* & B* \\
\hline Exam & - & $\checkmark$ & - & $\checkmark$ & - & - \\
\hline Non-assessed activities & \multicolumn{7}{|l|}{} & \multicolumn{7}{|l|}{} & & \\
\hline Research Activities & - & $\checkmark$ & - & - & - & - \\
\hline
\end{tabular}




\begin{tabular}{|l|l|l|l|l|l|l|}
\hline & \multicolumn{6}{|c|}{ Aff Environment Criteria } \\
\hline Reflection Activities & - & $\checkmark$ & $\checkmark$ & $\checkmark$ & $\checkmark$ & - \\
\hline Discussions & - & $\checkmark$ & $\checkmark$ & $\checkmark$ & $\checkmark$ & - \\
\hline
\end{tabular}

* FF, IF, P, R, Di, B: Formal feedback, Informal feedback, Practice knowledge / skills / understanding, Relevant tasks, Develop independence, Balanced formative and summative assessment.

Table 5: Current assessment scheme against assessment criteria

\begin{tabular}{|l|l|l|l|}
\hline & \multicolumn{3}{|c|}{ Assessment criteria } \\
\hline Assessment Scheme & $R^{*}$ & $Q^{*}$ & $F^{*}$ \\
\hline Exam & $\checkmark$ & - & - \\
\hline Non-assessed activities & & - & - \\
\hline Research Activities & $\checkmark$ & - & - \\
\hline Reflection Activities & - & $\checkmark$ & - \\
\hline Discussions & $\checkmark$ & $\checkmark$ & - \\
\hline
\end{tabular}

* R, QL, F: Reasonable in demand, Quality and Level of student effort, Feedback

The current LTA policy evaluation results show the different learning styles and competencies are not adjusted suitably. It did not embrace the University's LTA Strategy and some of ENU's principles such as 1) forming active learner, 2) emphasising collaborative learning, 3) personalising learning tasks, 4) using technology to enhance LTA of student learning, 5) proposing frequent formative assessment, 6) developing student autonomy (Edinburgh Napier University, 2010 \& 2013).

The evaluation above outlines the need to develop a well-structured and progressive timetable linked to LOs and to carry out an improved assessment scheme. It suggests the use of formative assessment and formal feedback provision with a need to use various assessment methods to test and increase students' employability skills. The evaluation scheme should also be an integral part of the learning process and promote learning as well as the application of knowledge while also providing formative feedback to the students about their overall performance (Juwah et al., 2004). The new version of the current LTA strategy should, therefore, ensure clarity, transparency and constructive alignment while considering critical feasibility criteria such as the V.R.P.C.F.U. factors. Additionally, some form of formative feedback on the module from students will be useful to reflect further on the module's overall effectiveness. 


\section{Chowdhry, S. Students' appraisal of current LTA Strategy}

Garnier, C.

\section{Data Collection}

Three semi-structured questionnaires (see Appendix I), were used to collect data at the beginning, middle and the end of trimester one. These questionnaires helped to evaluate the students' expectations by taking the module, to assess cognitive level achieved and attributes developed by current activities and assessment methods while also addressing any confusion and changes needed to improve students' experience and qualities. The combination of the questionnaires results helped in comparing with the time of answers.

\section{Data Analysis}

Surveys 1 and 2 had a $60 \%$ and $56 \%$ response rate respectively while the end-of-class questionnaire achieved a $48 \%$ response rate. This high response rate should allow the tutor to draw meaningful conclusions from the questionnaires outputs.

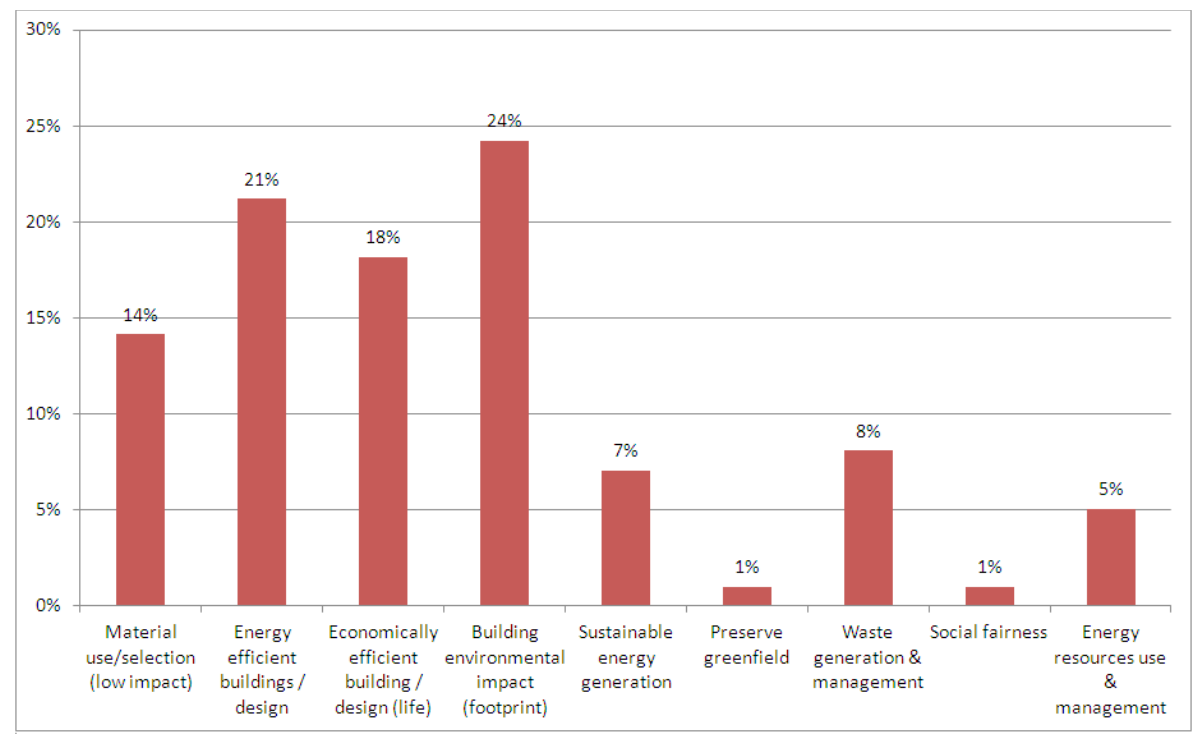

Figure 2: Initial student cohort understanding of what "Sustainable development" means

Figure 2 shows that students outlined all the concepts involved in sustainable development with an emphasis on buildings. 


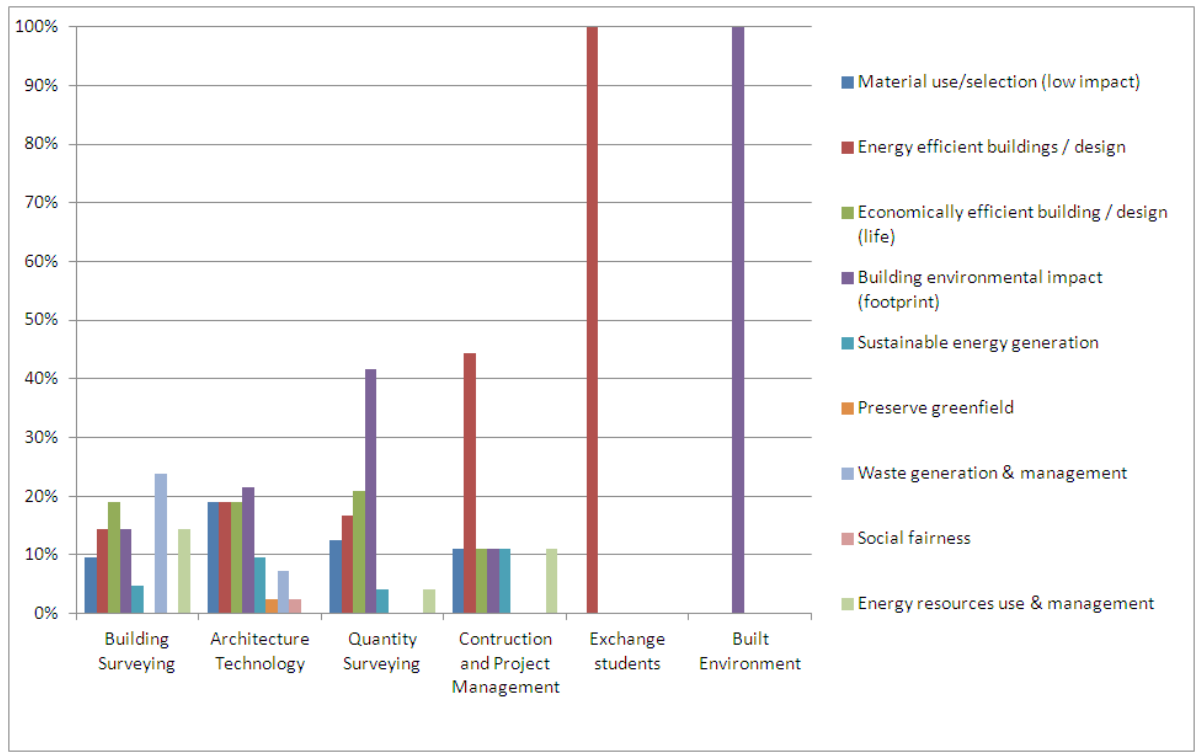

Evaluation of

Assessment

Method to

Incorporate

Graduate Attributes in Building Surveying Module

Figure 3: Student's programme share of what "Sustainable development" means Figure 3 further supports it, by showing the widespread across the student groups of different disciplines and their understanding of what sustainable development involves.

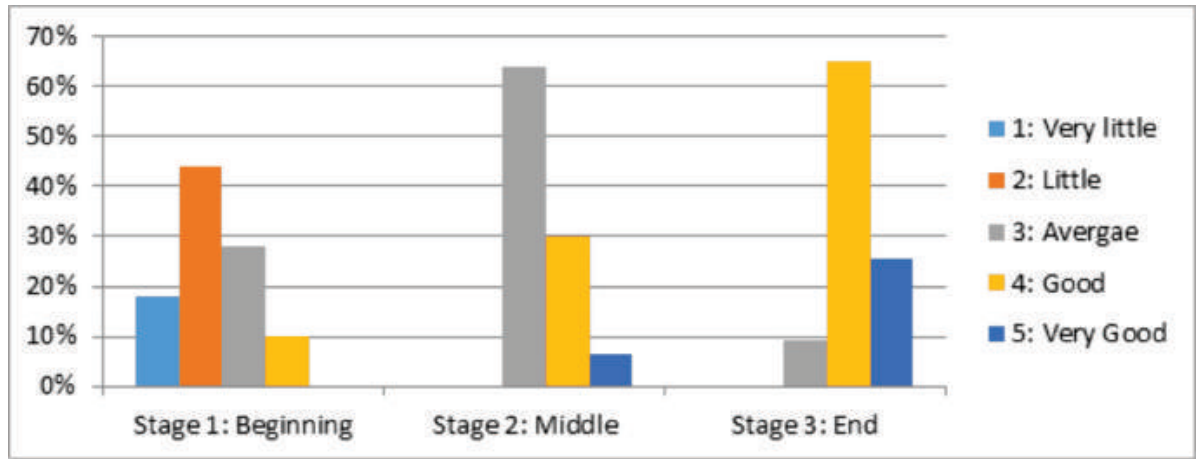

Figure 4: Percentage rate of students' understanding of Sustainable Development

Figure 4 below outlines that the students feel their knowledge of the topic has progressed significantly. At the beginning of the course, only $10 \%$ of students felt they had either a good or very good understanding of sustainable development, and it increased to $91 \%$ at the end of the module with a clear evolution as the module progressed (based on stage 2 results). Figure 5 and 6 below shows the students' aspirations are established 
Chowdhry, S. Garnier, C.

in the first questionnaire. All programs emphasised the integration of sustainability within their respective professions and passing the module as other desires.

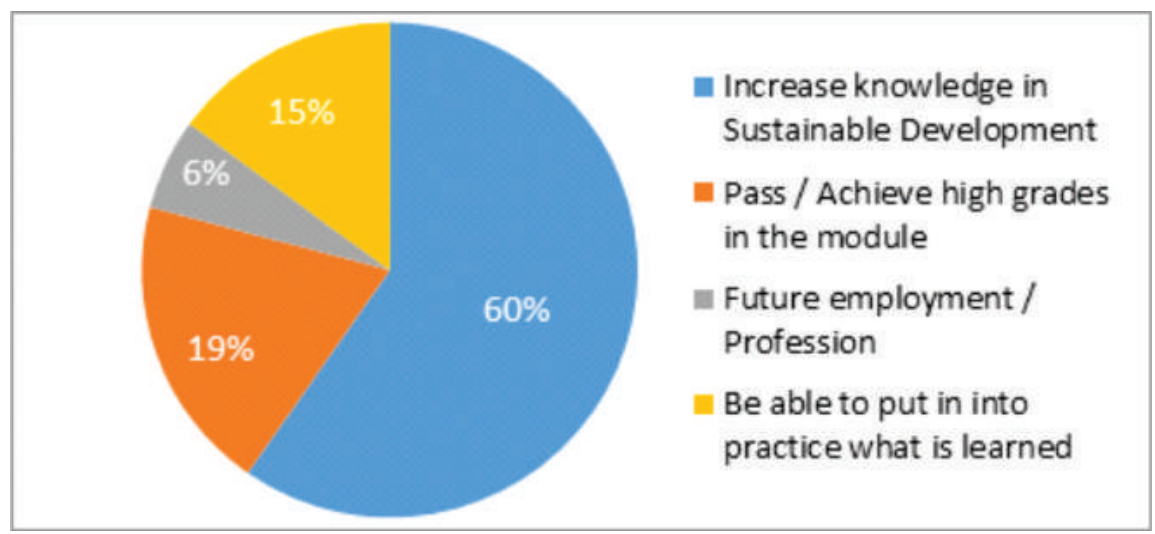

Figure 5: Students' initial rating of aspirations from undertaking BSV10104

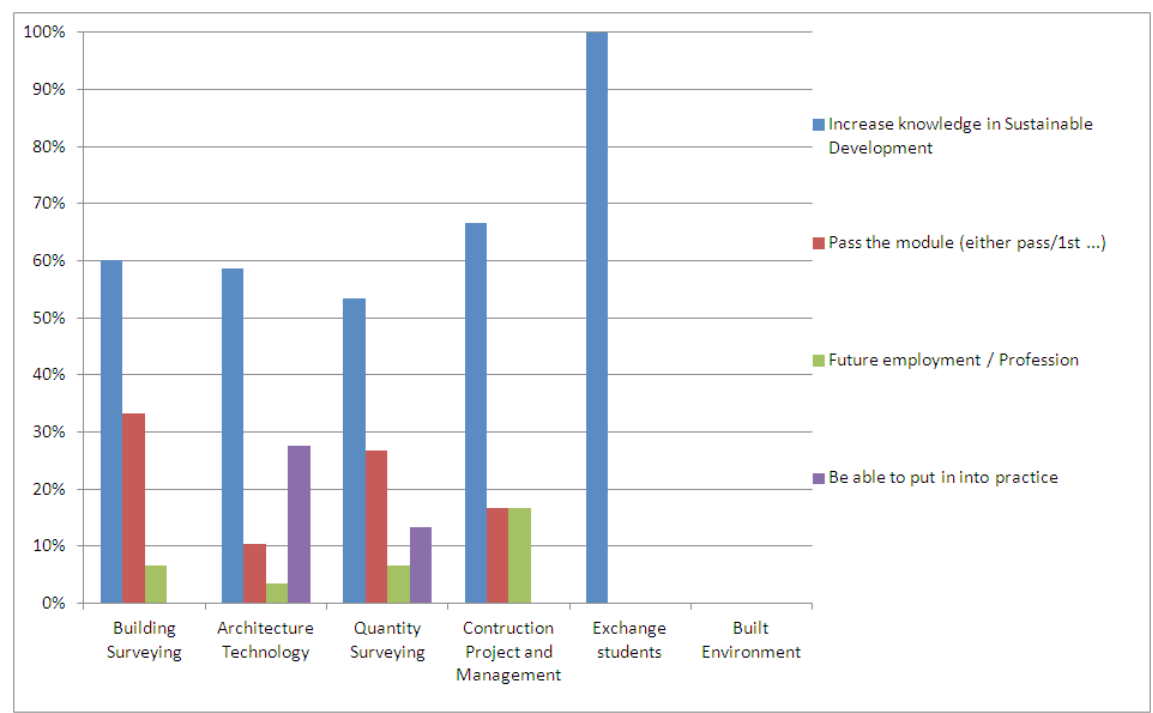

Figure 6: Students' initial aspirations rate by programme from undertaking BSV10104

Figure 5 and 6 below shows students' aims. All programs highlighted the integration of sustainability within their respective professions and passing the module as other wants. 


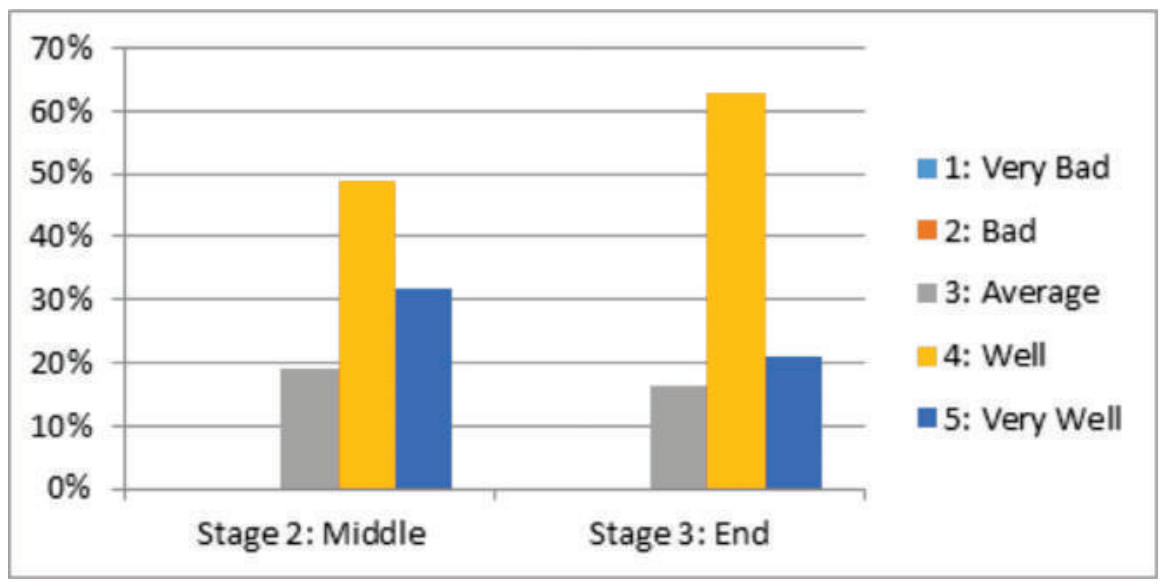

Evaluation of

Assessment

Method to

Incorporate

Graduate Attributes

in Building

Surveying Module

Figure 7: Students' rate on whether aspirations were achieved

Figure 7 suggests that students believe the course had achieved their ideals either well or very well at both the middle $(81 \%)$ and end of trimester $(84 \%)$ surveys.
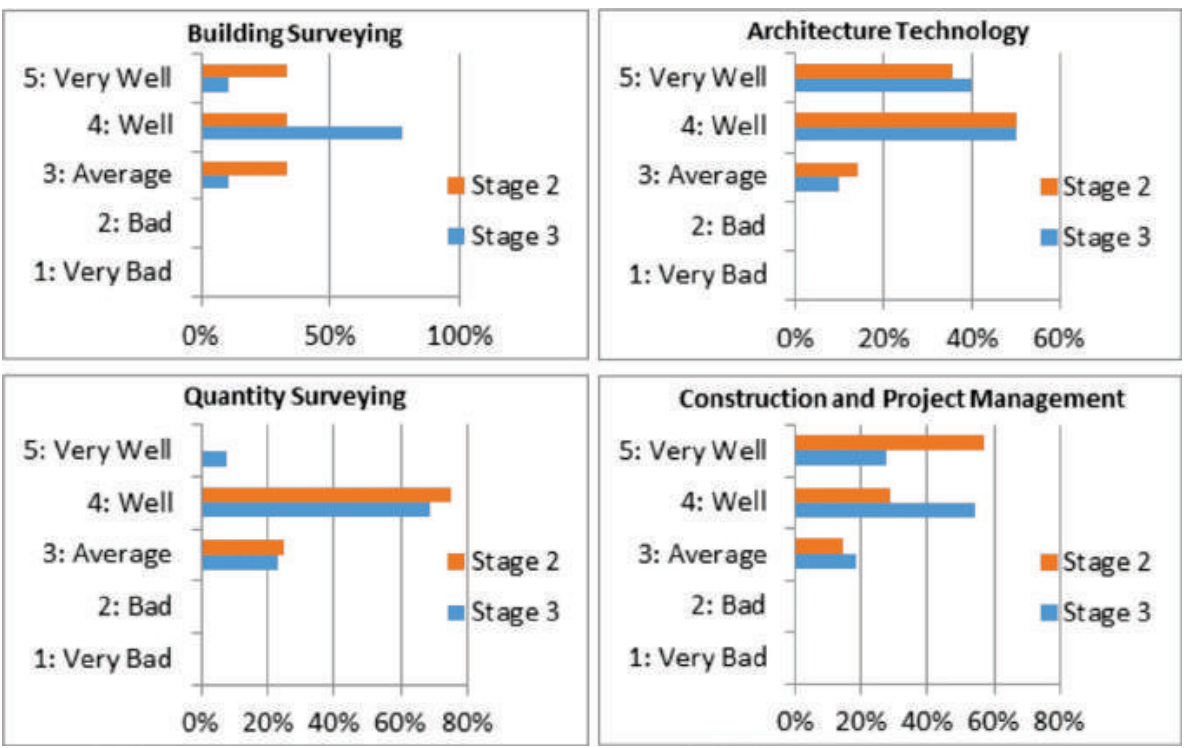

Figure 8: Evolution on whether aspirations were achieved by student cohorts

Figure 8 below however outlines a slight decline (from "Very Well" to "Well") in meeting student's ideals as the module progressed, mainly credited to Building Surveyors (BS) and Construction and Project Managers (CPM). 
Chowdhry, S.

Garnier, C.

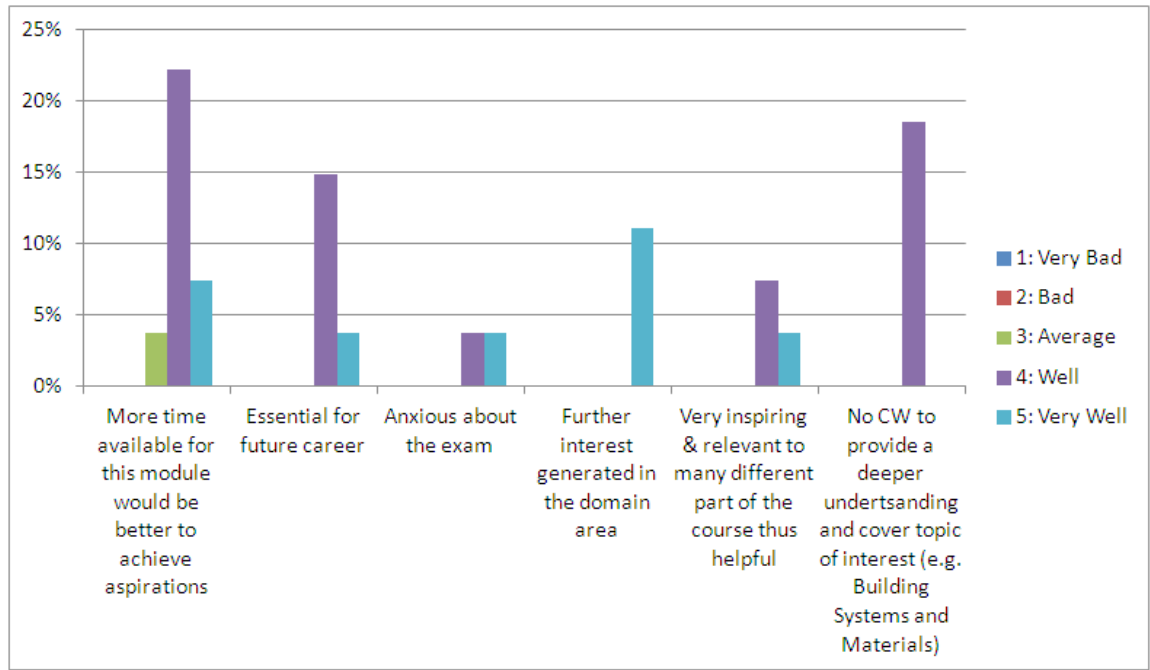

Figure 9: Students' comments their rating on whether aspirations were achieved

Figure 9 shows that students highlighted areas of good practices and positives outcomes while also outlining the need to apply further their knowledge and spend more time on the module.

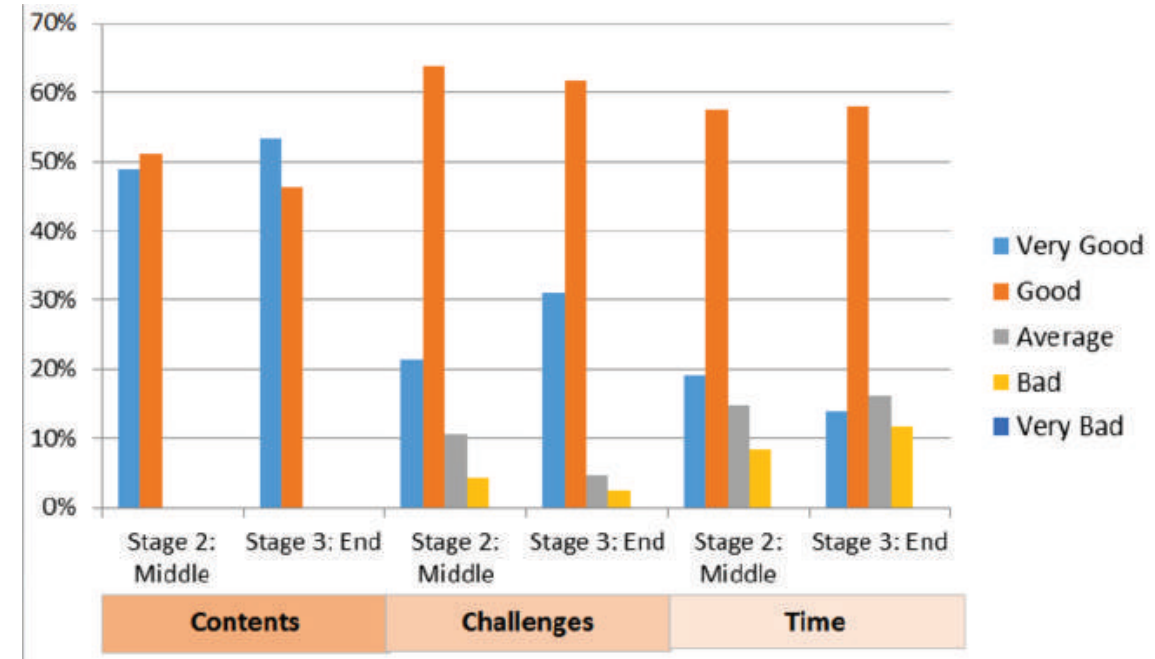

Figure 10: Students' opinion on teaching contents, materials and activities

Figure 10 suggests, the students rated the current course contents as being either good or very good in both the middle ( $85 \%)$ and end (93\%) of trimester surveys. 


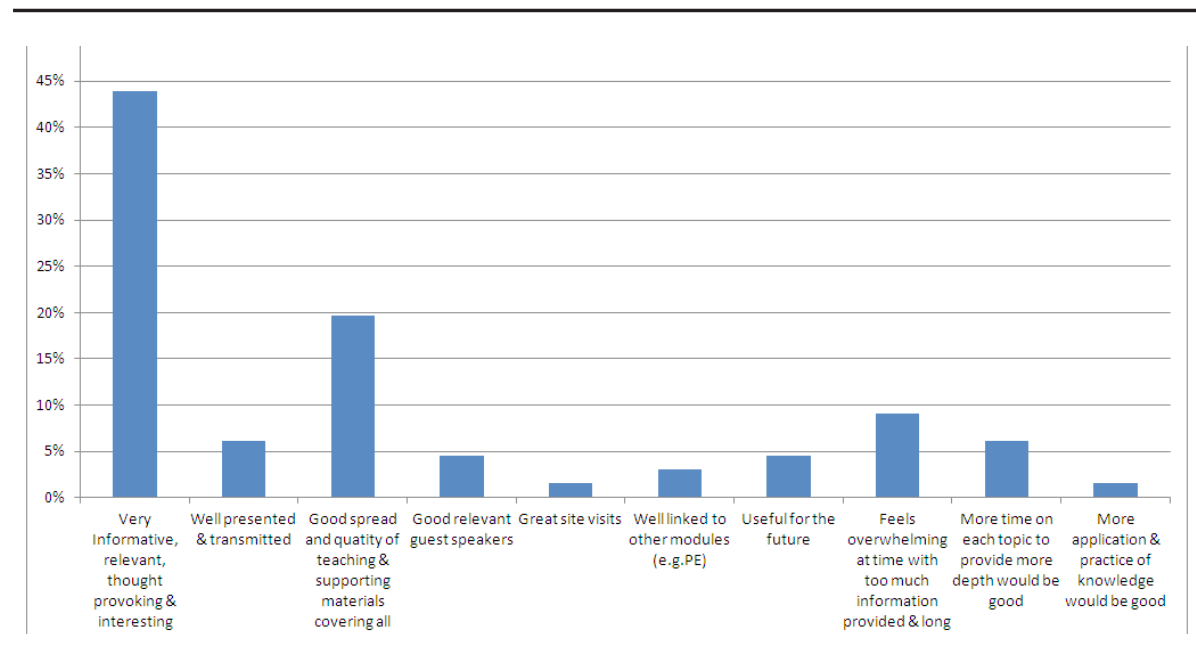

Evaluation of

Assessment

Method to

Incorporate

Graduate Attributes

in Building

Surveying Module

Figure 11: Students' comments on course contents

Comments from students shown in Figure 11 outlined good practices within the modules while also suggesting the quantity of information provided in classes can be overwhelming.

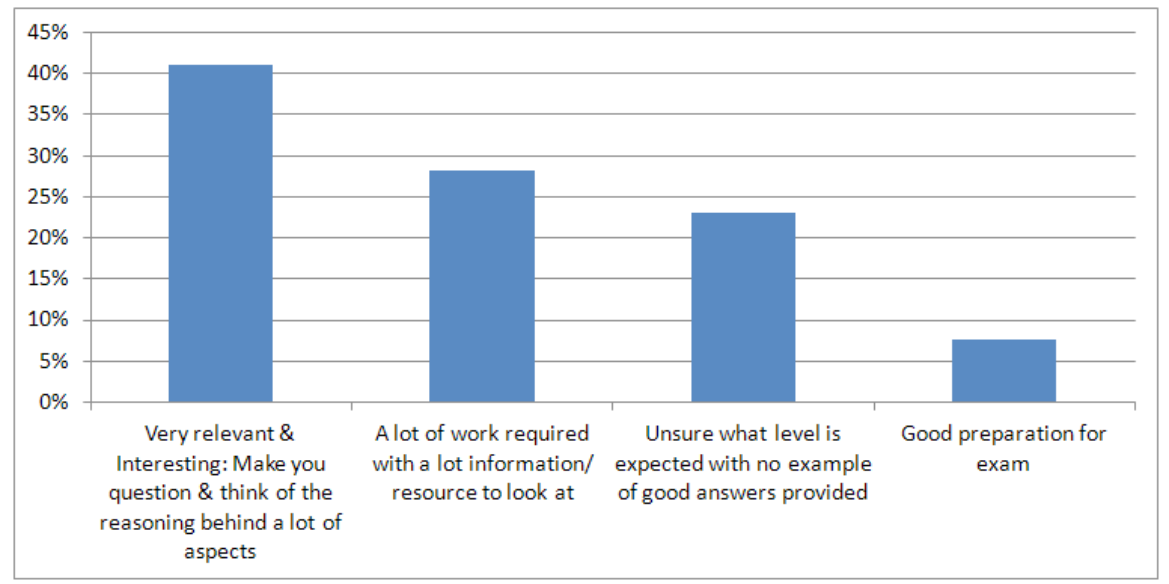

Figure 12: Students' comments on course challenges

Figure 12 shows how $49 \%$ of students felt the activities allowed them to develop reasoning and high cognitive skills and to prepare them for the exam. However, $28 \%$ of students felt it wanted a significant input from students while $23 \%$ felt the lack of support and expectations were not transparent. 
Chowdhry, S. Garnier, C.

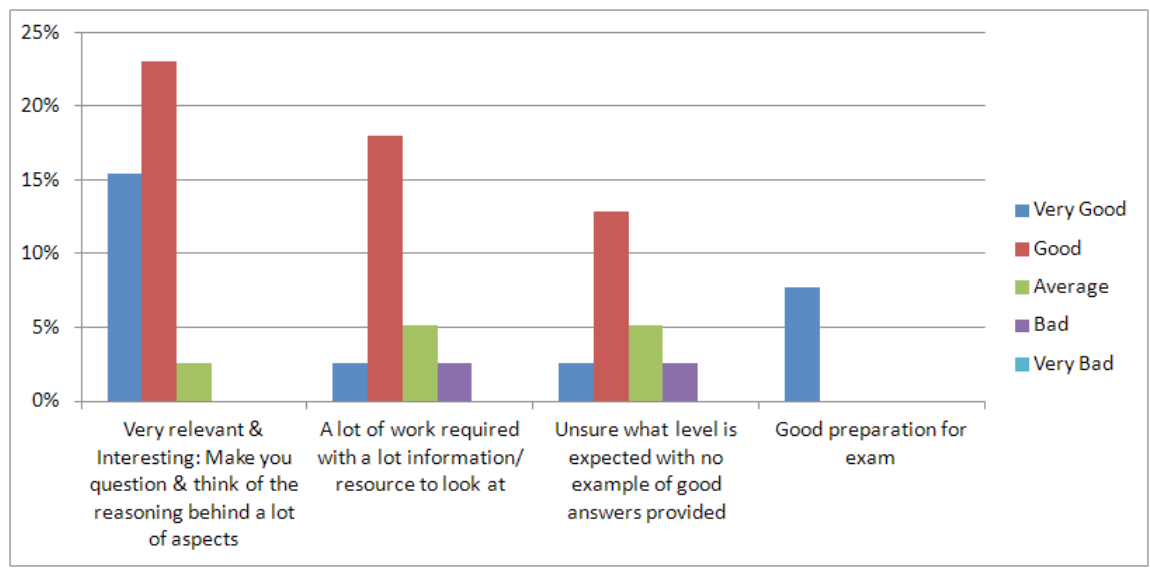

Figure 13: Students' comments on course challenges with rating

Figure 13 shows the issues outlined by students about high workload and lack of transparency/formal feedback apply to the whole cohort.

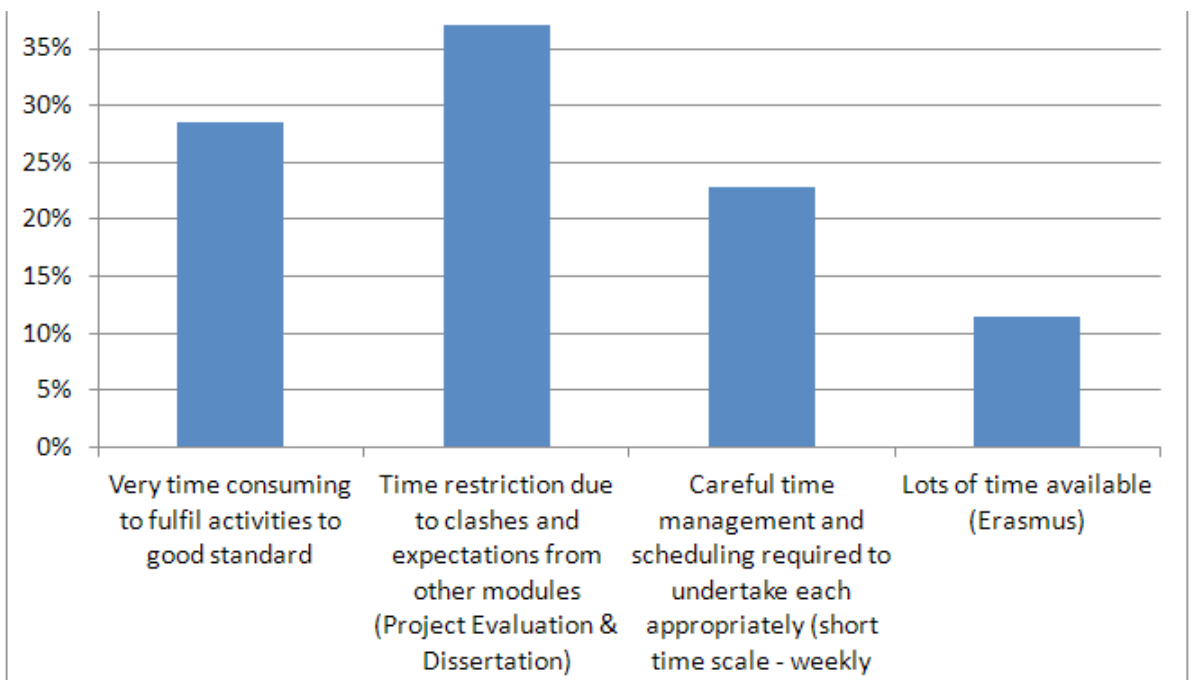

Figure 14: Students' comments on time available to undertake course activities

Figure 14 below shows that $23 \%$ of students felt the need to improve time-management skills to take all discussions in a timely and efficient manner. While another $66 \%$ could not undertake activities to the right standards due to the number of activities provided, time limits and 
expectations from other modules such as the Project evaluation and Dissertation modules.

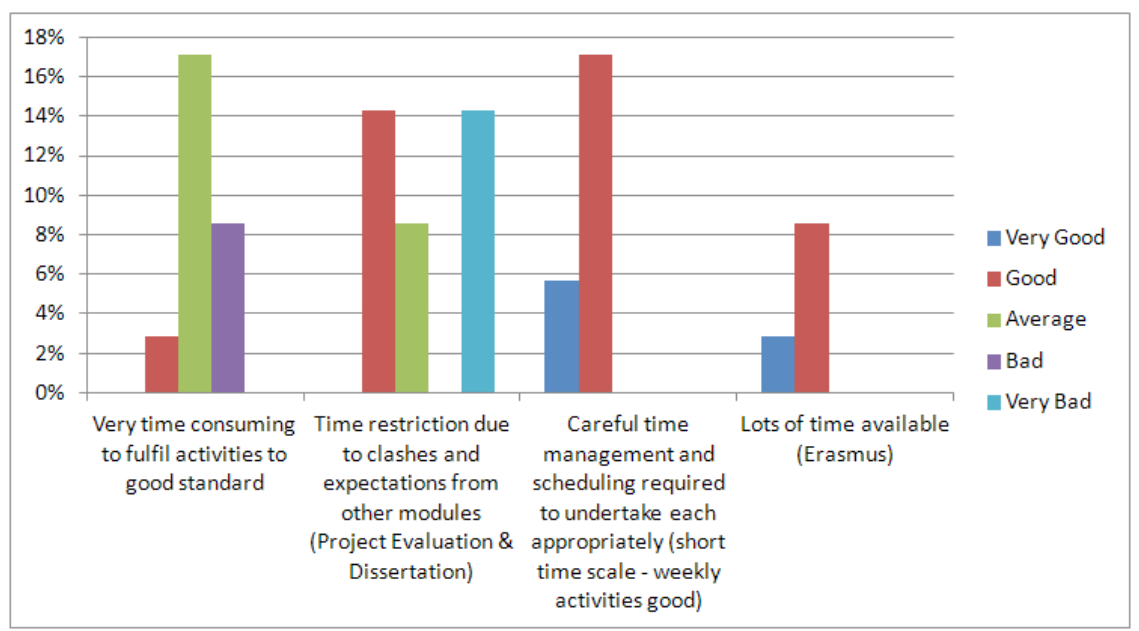

Figure 15: Students' comments on time available to undertake course activities with rating

Figure 15, displays the current activities may not be reasonable in demand about quantity and distribution towards the issue of time availability and clashes with other programs.
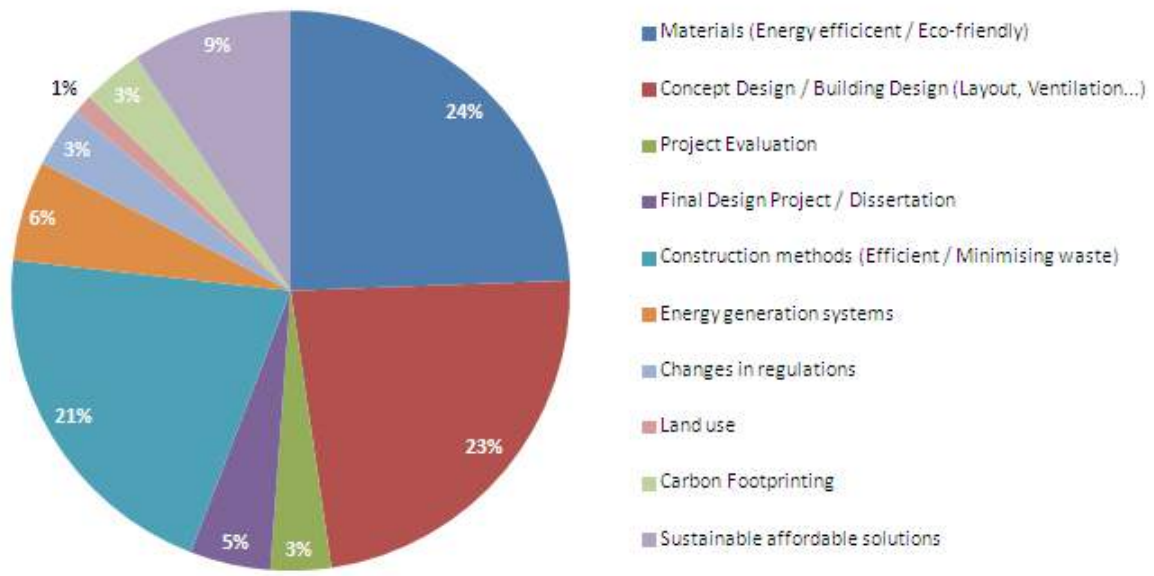

Figure 16: Overall student cohort rate of module relevance to programmes of study 
Chowdhry, S. Garnier, C.

Figure 16 outlines the overall student cohort opinion most of which directly link it, again, to buildings. However, linkage to other modules undertaken by students (e.g. Dissertation, Final Design Project and Project Evaluation) suggests, there is a real cohesion in their program of study with modules telling/feeding to each other. Students' linkage is in appropriate alignment with the topics covered in the module, thus providing confidence, the module should fulfil their ambition and integrate well with their individual programs.

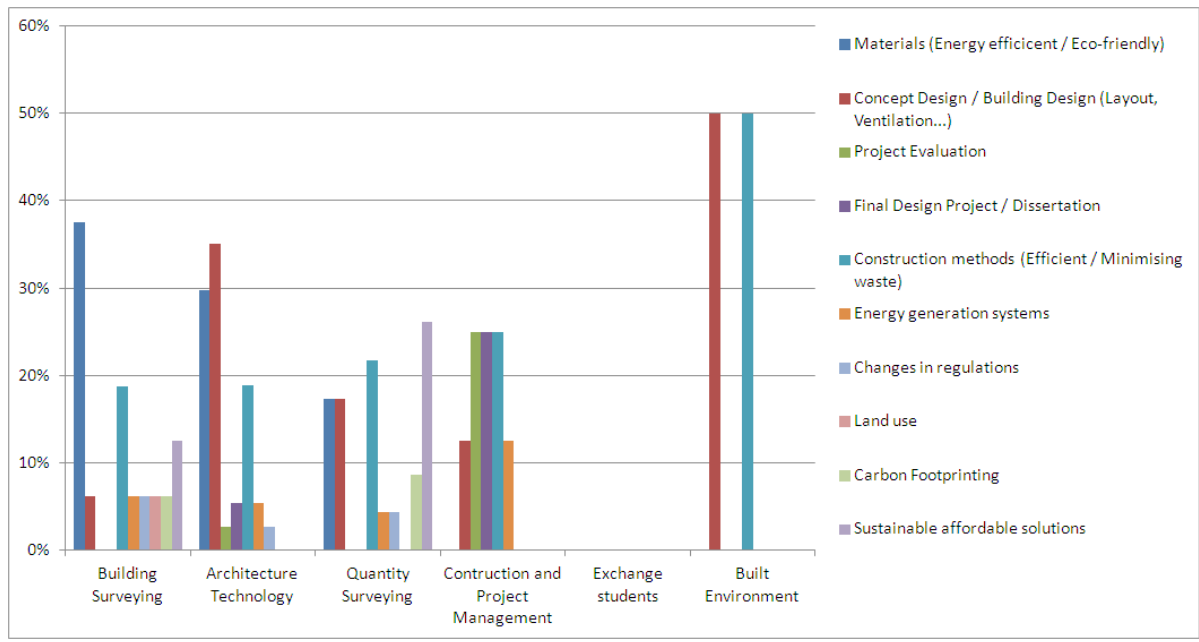

Figure 17: Student's rate of module relevance by programme

Figure 17 establishes the expected linkage of students from different programs. All mention "construction methods", thus emphasising "buildings" as an area of focus. Interestingly, each programme liaison to SD is with their speciality with BS relating more to "Materials"; Architecture Technologist (AT) to "Concept Design/ Building Design" and "Materials"; Quantity Surveyors (QS) to "Sustainable affordable solutions" thus including a cost factor. CPM to more "construction methods" mainly and Built Environment (BE) students to both "Building Design and "Construction methods". CPM students were, however, the only ones to clearly see the benefit of studying.

SD compared to their other modules, showing the "broad" vision expected from CPM graduates. 


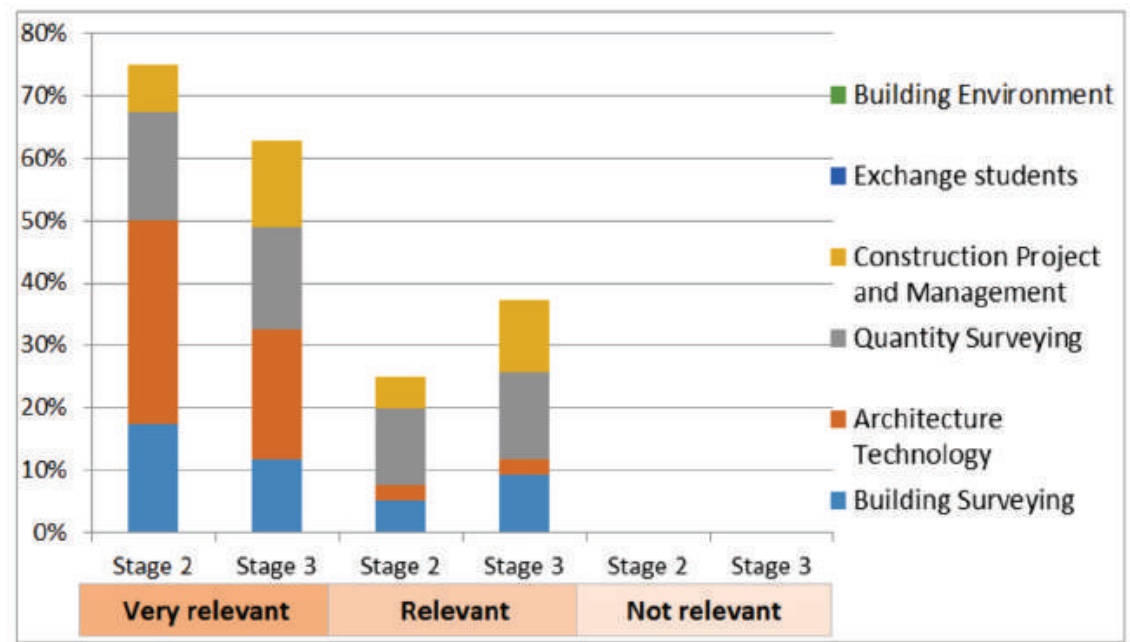

Evaluation of

Assessment

Method to

Incorporate

Graduate Attributes in Building Surveying Module

Figure 18: Percentage rate of Module relevance to programme of study

Figure 18 suggests that all students rated the current module as being either very relevant or relevant. The majority of students rated the current module as being very relevant to both the middle (75\%) and end $(63 \%)$ of trimester surveys. Whereas, Building Surveyors and Architecture Technologists rated decrease in relevance. Areas of interest previously outlined to "materials" and "concept/building design" as well as ideals to apply the knowledge, may be the reason for their low rating of the relevance.

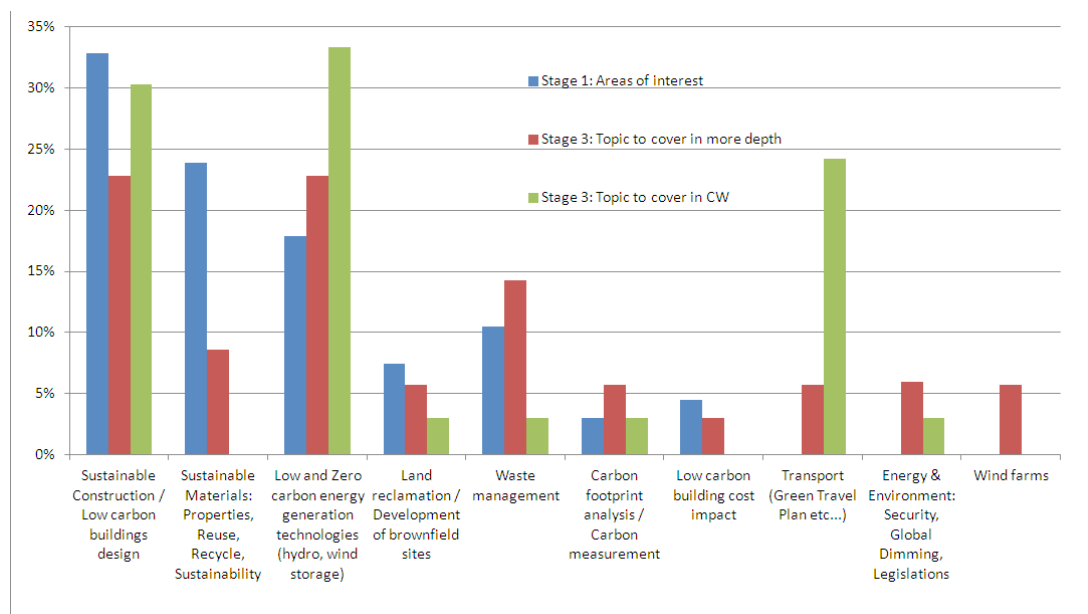

Figure 19: Students' opinion rate on areas of study to make BSV10104 more relevant to specific course and the cohort as a whole 
Chowdhry, S.

Garnier, C.

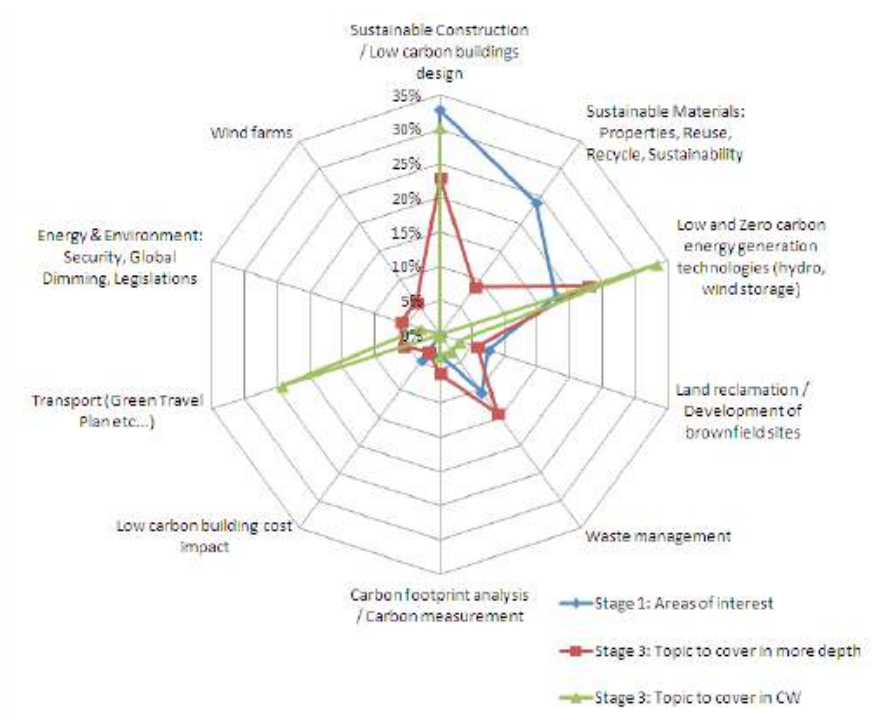

Figure 20: Students' percentage rate in change of opinion in areas of interest / topic to cover in more depth

Figure 19 and 20 clearly outline that the subject of sustainable construction and low carbon building designs remained an area of interest for students throughout the module while topics such as "low and zero carbon energy technologies" and "sustainable transport strategies" grew in popularity as the module progressed. These results indicate use of added assessment can further help in covering these possible areas.

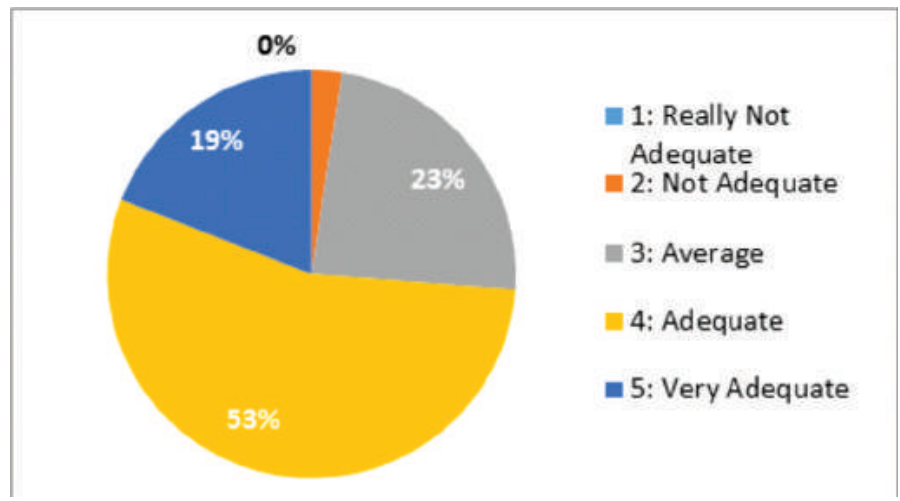

Figure 21: Students' opinion rate on adequacy of assessment method to test their abilities

Figure 21 suggests that about $72 \%$ of students identified the current evaluation methodology to be acceptable to test their knowledge and skills while $23 \%$ classify it as average and $2 \%$ as inadequate. 


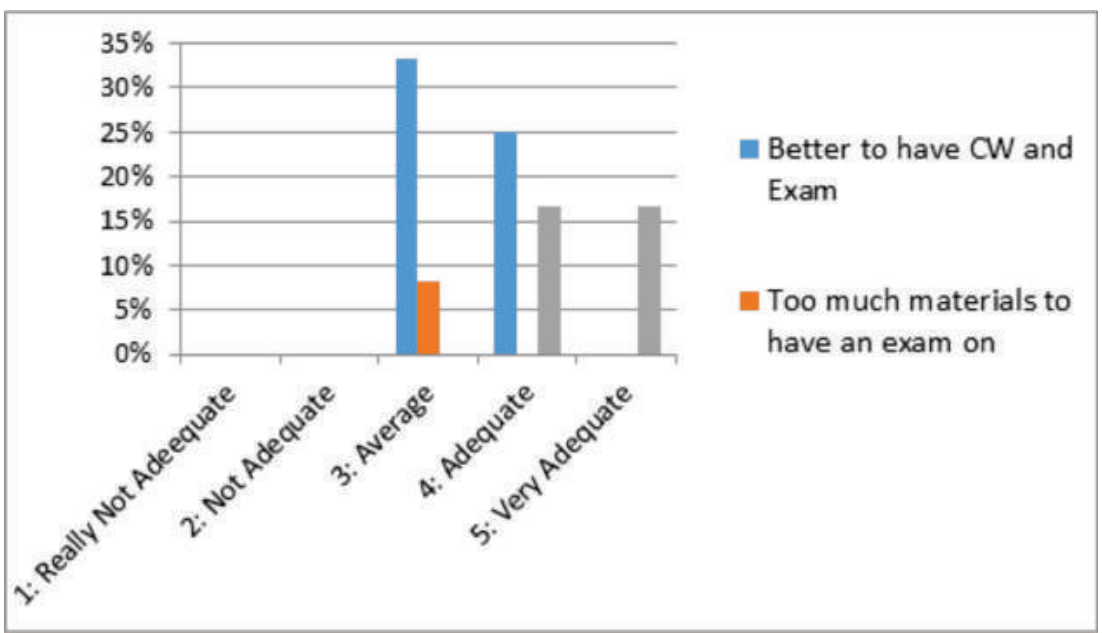

Evaluation of

Assessment

Method to

Incorporate

Graduate Attributes

in Building

Surveying Module

Figure 22: Students' comments on adequacy of assessment method in relation to their rating

Figure 22 shows that $58 \%$ would prefer to have an another marked formative assessment. Another $8 \%$ believe that an alternative to exam should assess such big topics and vast study material. Therefore these results suggest that $66 \%$ of students would support the implementation of some alternative or another method of assessment. It also outlines the possible need to narrow down the scope of the module to make it more accurate and thus not overwhelm students with a lot of materials.

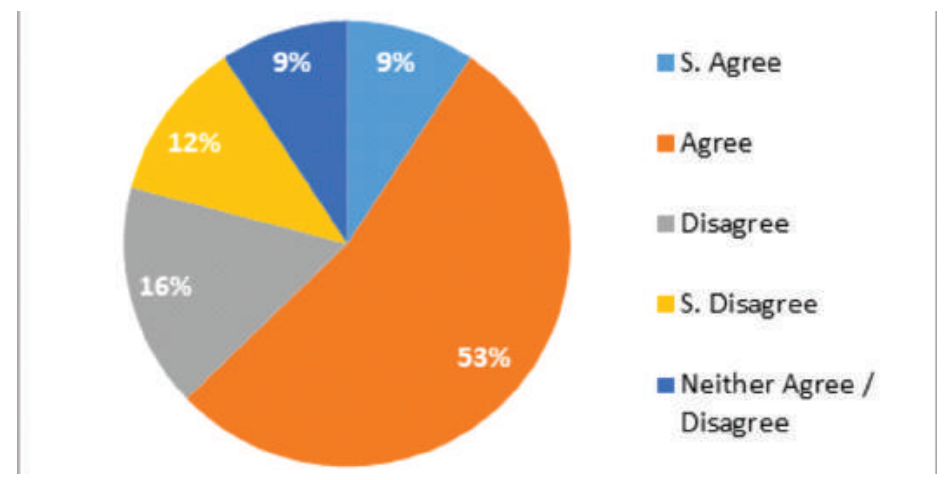

Figure 23: Students' opinion on whether a Coursework could be integrated

Figure 23 shows that only $41 \%$ suggested its integration to the Project Evaluation module. Unfortunately, such integration would not be feasible as the cohort includes Part-time and Erasmus students whose study structure does not contain project evaluation in the same year or at all. 
Chowdhry, S. Garnier, C.

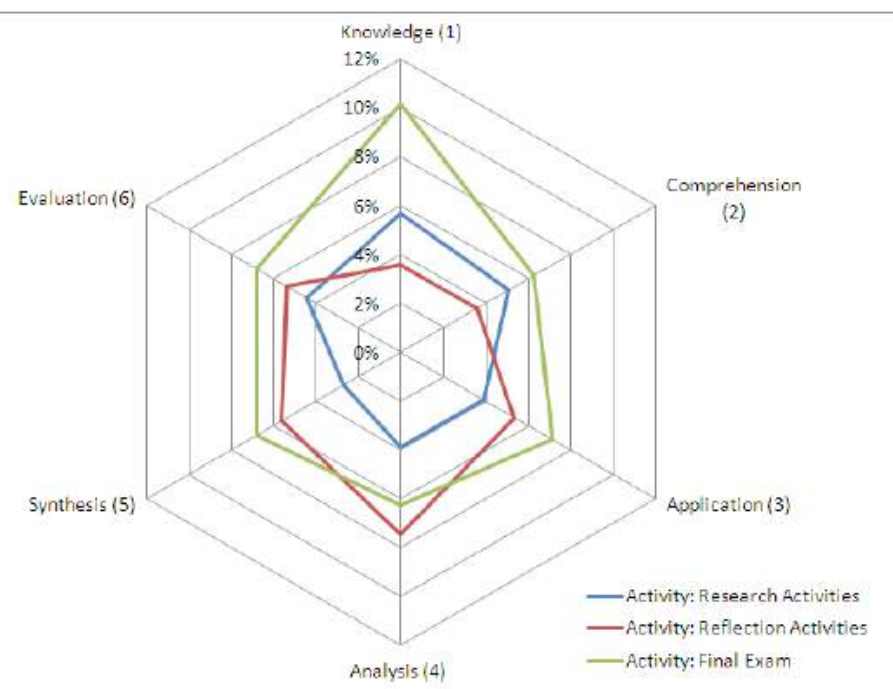

Figure 24: Cognitive level of module activities and assessment scheme

Figure 24shows the finalexamactivity achieved all levels of Bloom'scognitivedomain including two of the highest levels as it assessed students' individual knowledge as well as evaluation and synthesis skills in tackling theoretical application. However, most of the students identified this method as chiefly evaluate the lowest order of thinking "knowledge". Interestingly, research activities helped in awareness and understanding development, while reflection activities (and discussions) contributed to developing analysis than both the exam and research activities.

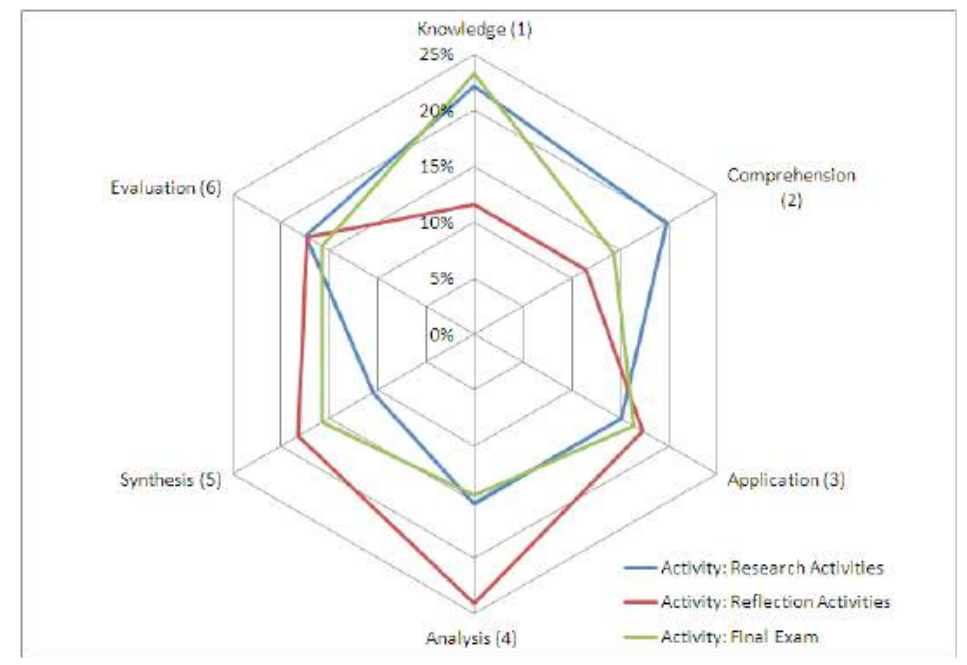

Figure 25: Module's individual activities and level of cognition 
Figure 25 shows that the final exam has a cognitive distribution of $23 \%$ knowledge, $14 \%$ understanding, $16 \%$ application, $14 \%$ analysis, $16 \%$ synthesis, and $16 \%$ evaluation. It outlines that $40 \%$ of the students identified exam to challenge them at the lower cognitive levels while $60 \%$ challenged the students at, the higher cognitive levels. Additionally, $24 \%$ of the reflection activities and $42 \%$ of the research activities challenged students at the lower cognitive levels while $78 \%$ and $58 \%$ of the thinking and research activities respectively challenged the students at the higher cognitive levels. It explains the research activities overall have a greater impact on students' learning. Table 6 shows students evaluation of the portion of lower and higher cognitive level in each assessment exercise.

Table 6: Students' evaluation of available assessment methods and level of cognition

\begin{tabular}{|l|c|c|}
\hline & $\begin{array}{c}\text { Lower Cognitive } \\
\text { Levels }\end{array}$ & $\begin{array}{c}\text { Higher Cognitive } \\
\text { Levels }\end{array}$ \\
\hline Problem Based Learning report & $46 \%$ & $54 \%$ \\
\hline Individual Written report & $43 \%$ & $57 \%$ \\
\hline Group Written report & $36 \%$ & $64 \%$ \\
\hline Individual Presentations & $38 \%$ & $62 \%$ \\
\hline Group Presentations & $39 \%$ & $61 \%$ \\
\hline Poster Presentations & $36 \%$ & $64 \%$ \\
\hline Quizzes & $48 \%$ & $52 \%$ \\
\hline Midterm exams & $42 \%$ & $58 \%$ \\
\hline Final Exam & $42 \%$ & $58 \%$ \\
\hline
\end{tabular}

The resulting cognitive analysis describes that group written reports, poster presentations and individual and group presentations hold more merits among students as achieving higher cognitive levels while quizzes, PBL report have a greater proportion of lower cognitive levels. Individual written reports and mid and final exams were all set up to challenge students between 44 to $45 \%$ at the lower cognitive levels and 57 to $58 \%$ at the higher cognitive levels.

\section{Audit of BSV10104 current method of assessment}

Different audit tools and a checklist (see Appendix II) helped in a self-assessment of the current BSV10104 assessment scheme.

The "Assessment Audit Tool" uses a numeric scoring system from 0 (not considered) to 4 (optimally satisfied) and analyses audit points scoring
Evaluation of

Assessment

Method to

Incorporate

Graduate Attributes in Building Surveying Module 
Chowdhry, S. Garnier, C.

2 or less. By making a subjective judgment and scoring various aspects of assessment included in the audit tool helped to identify some of the main issues occurring within the BSV10104 assessment scheme such as 1) assessing students' abilities, 2) while developing alternate assessment, need to consider plagiarism, students' workload and marking overload, 3) unclear marking criteria, 4) exemplary answers not available, 5) students are not continuously assessed, 6) all students do not receive feedback.

The "Employability Audit Tool" used the same scoring system as the "Assessment Audit Tool" above. Although mainly developed for a program level analysis, some sections did also apply to modules. The areas of improvements are, 1) academic staff should be informed about the employers and their procedure of judging the strengths and weakness of the student, 2) use of realistic simulations in teaching, 3) assessing students' generic skills, 4) to give assessment choice to the students.

The "Module Evaluation Checklist" helped in identifying improvements in teaching practice such as 1) consideration of students' workloads, 2) periodically assessed self-tests or reflective tasks/activities should be used to ensure students' engagement and development, 3) online communication and collaboration on the main tasks.

All evaluation methods support the use of an alternative method of assessment to be developed to support different learning styles and interests, check student's development, provide formal feedback and develop lifelong learning skills. The proposed method should, however, consider the impact it has on students and staff workloads. Additionally, a clear hint of students' strengths and weaknesses made out by graduate employers' would be highly useful to tell module contents and evaluation methods.

\section{Proposed Assessment Strategy}

In the proposed assessment (see Appendix III), the reflection activities are adjusted to become interactive online discussion and their numbers reduced to consider the overall student's workloads. The interactive online discussion is encouraged to strengthen interchange of ideas, develop their analysis and critical skills, and provide lifelong learning skills. A small credit (5\%) could be granted to student's participation in this activity to encourage students' involvement. Removed research activities as they did not have a significant impact on students learning. The final traditional exam assessment method will be adapted to encompass another form of assessment.

A problem-based learning real case scenario on "sustainable 
construction/ low carbon building designs" is introduced to students in the first week of teaching. About four to five issues may be provided with the case scenario. These would be developed in alignment to LOs and to reflect the different interests identified within the large student cohorts (e.g. Current and added green value; Green designed features and potential; Costs assessment and sustainable impact; Building materials sustainability and footprint; Energy and sustainable technologies). Students need to join online one of the groups looking at one particular issue from the list provided by the tutor. A group will have 6 to 8 members. Students, then go through the PBL seven classical steps and present their findings as well as the methods they used to tackle their particular topic (thus outlining how they addressed the PBL steps). The group output may be either through group poster display or group presentations which could occur in week eight as this does not collide with any of the Project Evaluation or Dissertation Modules submissions and intermediate presentations weeks. This group work element would allow students to develop skills and to learn from the experience and knowledge of their peers. Detailed formal feedback on their work including contents, presentation, structure, methods, strengths and weaknesses and how they meet or not the marking scheme wants could then be provided immediately by a group to group peer-assessment and a panel of markers. This arrangement will overcome the issue of non-anonymous marking and ensure fairness of the assessment scheme. Time spent on feedback, have to be managed by using criterion focused feedback form. Additionally, including a form of team peer-assessment and self-assessment against a predefined evaluation criterion grid will overcome the impact of having poor performers penalising a group's overall performance. As a result, a strategic decrease may be applied in the exam to balance the tutors' workload. Instead of students having to answer four out of six questions, the exam may be structured in three questions. Question one will be compulsory and related to the group assignment projects. Specific questions on each listed topics will be provided. This first question is likely to cover LOs 3-5 (see Appendix I). Students will have the choice to answer two of the three remaining questions which may be developed with the interactive online discussions.

\section{Proposed New Assessment Scheme Evaluation}

The new proposed assessment scheme evaluation using the "V.R.P.C.F.U." criteria is shown in Table 7 below, Bloom's cognitive domain (Table 8), graduates' employability skills (Table 9)and assessment for learning criteria (Table 10 and 11).
Evaluation of

Assessment

Method to

Incorporate

Graduate Attributes in Building Surveying Module 
Chowdhry, S. Garnier, C.

Table 7: Proposed assessment scheme considered against the five key criteria

\begin{tabular}{|c|c|c|c|c|c|}
\hline \multirow[t]{2}{*}{ Assessment Scheme } & \multicolumn{5}{|c|}{ Key Criteria } \\
\hline & $V^{*}$ & $\mathbf{R}^{*}$ & $\mathbf{P} \& \mathbf{C}^{*}$ & $F^{*}$ & $\mathbf{U}^{*}$ \\
\hline Peer-assessment marking & - & $\mathrm{P}$ & $\mathrm{P}$ & $\mathrm{P}$ & $\mathrm{P}$ \\
\hline Self-assessment marking & - & $\mathrm{P}$ & $\mathrm{P}$ & $\mathrm{P}$ & $\mathrm{P}$ \\
\hline Group-assessment marking & - & $\mathrm{P}$ & $\mathrm{P}$ & $\mathrm{P}$ & $\mathrm{P}$ \\
\hline Group/Poster Presentations & $\mathrm{P}$ & $\mathrm{P}$ & - & $\mathrm{P}$ & $\mathrm{P}$ \\
\hline Interactive online discussions & $\mathrm{P}$ & - & $\mathrm{P}$ & $\mathrm{P}$ & $\mathrm{P}$ \\
\hline Final exam & $\mathrm{P}$ & $\mathrm{P}$ & $\mathrm{P}$ & - & - \\
\hline
\end{tabular}

*V.R.P.C.F.U..: Validity, Reliability, Practicality and Cost effectiveness, Fairness and Usefulness

Table 8: Proposed assessment scheme considered against Bloom's cognitive domain

\begin{tabular}{|l|l|l|l|l|l|l|}
\hline \multirow{2}{*}{ Assessment Scheme } & \multicolumn{6}{|l|}{ Bloom's cognitive domain } \\
\cline { 2 - 8 } & K* & C * & Ap * & An * & S* & E* \\
\hline Peer-assessment marking & - & - & - & - & $\checkmark$ & $\checkmark$ \\
\hline Self-assessment marking & - & - & - & - & $\checkmark$ & $\checkmark$ \\
\hline Group-assessment marking & - & - & - & - & $\checkmark$ & $\checkmark$ \\
\hline Group/Poster Presentations & $\checkmark$ & $\checkmark$ & $\checkmark$ & $\checkmark$ & $\checkmark$ & $\checkmark$ \\
\hline Interactive online discussions & - & - & $\checkmark$ & $\checkmark$ & $\checkmark$ & $\checkmark$ \\
\hline Final exam & $\checkmark$ & $\checkmark$ & - & $\checkmark$ & $\checkmark$ & $\checkmark$ \\
\hline
\end{tabular}

*K.C.Ap.An.S.E.: Knowledge, Comprehension, Application, Analysis, Synthesis, Evaluation. Table 9: Proposed assessment scheme considered against employability skills

\begin{tabular}{|l|l|l|l|l|l|l|l|l|}
\hline \multirow{2}{*}{ Assessment Scheme } & \multicolumn{7}{|l|}{ Employability skills and attributes } \\
\cline { 2 - 9 } & P* & Co* & Cr* & I* & D* & T* & M* & N* \\
\hline Peer-assessment marking & - & $\checkmark$ & $\checkmark$ & - & $\checkmark$ & - & - & - \\
\hline Self-assessment marking & - & - & $\checkmark$ & - & $\checkmark$ & - & - & - \\
\hline Group-assessment marking & - & $\checkmark$ & $\checkmark$ & - & $\checkmark$ & - & - & - \\
\hline Group/Poster Presentations & $\checkmark$ & $\checkmark$ & $\checkmark$ & $\checkmark$ & $\checkmark$ & $\checkmark$ & $\checkmark$ & $\checkmark$ \\
\hline Interactive online discussions & $\checkmark$ & $\checkmark$ & $\checkmark$ & $\checkmark$ & $\checkmark$ & - & $\checkmark$ & $\checkmark$ \\
\hline Final exam & $\checkmark$ & - & $\checkmark$ & $\checkmark$ & - & - & $\checkmark$ & $\checkmark$ \\
\hline
\end{tabular}

* P, Co, Cr, I, D, T, M, N: Problem formulation and solving, communication and cooperation, critical and creative thinking, independent learner, decision-making, teamwork and group leadership, management of time and resources; and numeracy and intellectual skills. 
Table 10: Proposed assessment scheme considered against assessment for learning (Afl) environment criteria

\begin{tabular}{|l|c|c|c|c|c|c|}
\hline \multirow{2}{*}{ Assessment Scheme } & \multicolumn{6}{|c|}{ Afl environment criteria } \\
\cline { 2 - 7 } & FF* & IF* & P* & R* & Di* & B* \\
\hline Peer-assessment marking & $\checkmark$ & - & $\checkmark$ & - & $\checkmark$ & $\checkmark$ \\
\hline Self-assessment marking & $\checkmark$ & - & $\checkmark$ & - & $\checkmark$ & $\checkmark$ \\
\hline Group-assessment marking & $\checkmark$ & - & $\checkmark$ & - & $\checkmark$ & $\checkmark$ \\
\hline Group/Poster Presentations & $\checkmark$ & - & $\checkmark$ & $\checkmark$ & $\checkmark$ & $\checkmark$ \\
\hline Interactive online discussions & - & $\checkmark$ & $\checkmark$ & $\checkmark$ & $\checkmark$ & $\checkmark$ \\
\hline Final exam & - & $\checkmark$ & - & $\checkmark$ & - & - \\
\hline
\end{tabular}

* FF, IF, P, R, Di, B: Formal feedback, Informal feedback, Practice knowledge / skills / understanding, Relevant tasks, Develop independence, Balanced formative and summative assessment.

Table 11: Proposed assessment scheme considered against assessment criteria

\begin{tabular}{|l|c|c|c|}
\hline \multirow{2}{*}{ Assessment Scheme } & \multicolumn{3}{|c|}{ Assessment criteria } \\
\cline { 2 - 4 } & R $^{*}$ & QL $^{*}$ & F* $^{*}$ \\
\hline Peer-assessment marking & $\checkmark$ & $\checkmark$ & $\checkmark$ \\
\hline Self-assessment marking & $\checkmark$ & $\checkmark$ & $\checkmark$ \\
\hline Group-assessment marking & $\checkmark$ & $\checkmark$ & $\checkmark$ \\
\hline Group/Poster Presentations & $\checkmark$ & $\checkmark$ & $\checkmark$ \\
\hline Interactive online discussions & $\checkmark$ & $\checkmark$ & $\checkmark$ \\
\hline Final exam & $\checkmark$ & - & - \\
\hline
\end{tabular}

* R, QL, F: Reasonable in demand, Quality and Level of student effort, Feedback

This new assessment scheme balances formative and summative assessments. The variety of assessment methods used considers different learning styles and accounts for diversity and the development of graduate attributes. The use of clear marking criteria, anonymous team peer-review, peer group review and panel marking, as well as the inclusion of a self-assessment and one project based exam question, strengthens the fairness of the assessment scheme.

It increases the usefulness of the proposed assessment plan compared with the current one. Not only can it promote effective learning strategies through varied progressive tasks, but it can also provide timely formative feedback to students. It encourages students to share ideas, thinks critically, present rational arguments and challenges themselves. Hounsell (2003) suggests that students' involvement in the generation of feedback is valuable to their overall experience
Evaluation of Assessment Method to Incorporate Graduate Attributes in Building Surveying Module 
Chowdhry, S. Garnier, C.

and encourage more self-reflection on their personal attainment. The scheme would thus provide lifelong learning and employability skills as well as promote a deeper approach to learning. Additionally, this assessment plan supports the application of knowledge within real contexts while also encourage competence development. Therefore, it strengthens the usefulness of this evaluation scheme.

Although the time needed to set-up, the whole assessment plan may be demanding, and good management will make it practical and profitable. Teampeer, self and peer group assessments, as well as the panel assessment, can be immediate. Additionally, the work in collating marks should not impact the tutors' workload significantly, and postgraduate students could support the data entry. Groups of 6 to 8 students could be formed, thus resulting in 12 to 15 groups. A strict presentation time of the work followed by Q\&A would be used to ensure it is manageable. Although the integration of a group presentation would clearly benefit this module, there may be concerns with using the same assessment method employed in another module within the same year. It may be addressed by considering the implementation of a group poster display and presentation instead. It could be done during tutorial times running over two weeks and could thus be more manageable. Another assessment method could thus be partially integrated within the module activity to ensure the overall students' workload is reasonable.

A self-assessment of the newly developed BSV10104 assessment scheme using the same previously used audit tools and checklist was undertaken. This evaluation outlined that most of the issues identified in the current assessment plan were dealt with by the proposed assessment scheme. Although the study considered students and staff's workloads, the author still feels it as one possible issue needing further attention. More information from employers would, again, be useful to tell academic staffs on further developments requiring implementation. These should thus be addressed.

It implies, the university may encourage academic staff to get familiar with the effective learning strategies, different types of assessments, students learning styles and in an evaluation of the assessment strategy with the Graduate Attribute model. Information from the Human Resource Department and the Research Department will be useful while proposing a new assessment strategy to raise the students learning experience, as the assessment strategy will also help in optimising the academic staff's workload, thus enabling them to conduct research with teaching.

\section{CONCLUSIONS}

The aim of the study was to find out whether an alternative assessment strategy can improve the student's learning experience and, employability skills 
and attributes in the BSV10104 module. In particular the current study had five objectives 1) To appraise the factors influencing assessment strategies, 2) To identify assessment strategies available for increased learning in large cohort, 3) To evaluate current assessment practice and explore development of the new methods of assessment within the BSV10104 module, 4) Identify the area for development, 5) Assess how the new proposed assessment strategy could strengthen graduate employability skills and attributes. The study has found the need to change the current assessment scheme of the Sustainable Developments module.

A new proposed assessment strategy included the range of features to improve the students learning experience. For instance, use of interactive online discussions for reflection and grant of 5\% marks for the student's participation in online activities. Second, removal of the research activities. Third, use of the traditional exam assessment method to encompass an added assessment. Fourth, introduction of PBL real case scenario on "Sustainable construction / low carbon building design". Fifth, formation of online groups will provide opportunities for collaborative learning". Sixth, provision of detailed formal feedback for the students. Also, the introduction of peer-assessment and self-assessment marking strategies to provide immediate feedback to the large student's cohorts.

The criteria's used to evaluate the feasibility of the new proposed assessment strategy are 1) Five key criteria test, 2) Bloom's cognitive domain test, 3) Employability skills and attributes analysis and 4) Assessment for learning environment test. The proposed added method of assessment complements well the current traditional written examination. Not only can it encourage students' involvement and adoption of the deep-level approach to learning, but it can also develop employability skills through summarising complex information, communicating the findings, and working within a team.

It implies, the university may encourage the continuous professional development of the academic staff and promote evaluation of the assessment strategy with the Graduate Attribute model. Information from the Human Resource Department and the Research Department will help in proposing new assessment strategy to heighten students experience and provide an opportunity to the academic staff to conduct research.

A suggested direction for further research is to create as assessment model by triangulating data on the students learning styles, assessment strategies and the workload information.

\section{BIOGRAPHIES}

Sandeep Chowdhry has studied in India and the UK. In the past, he has worked as a lecturer in Mechanical Engineering in India. At present, he is
Evaluation of

Assessment

Method to

Incorporate

Graduate Attributes

in Building

Surveying Module 
Chowdhry, S. $\quad$ working as a lecturer in Product Design and is a Teaching Fellow at Edinburgh Garnier, C. Napier University. He is interested in research in Education and Mechanical Engineering.

Celine Garnier graduated and worked in France in Thermodynamic and Energy. She completed the Masters and PHD studies at Edinburgh Napier University (ENU) and is working as a Senior Lecturer at ENU. She has been publishing journal articles in Computational Fluid Dynamics and have experience of field testing energy systems. She has also studied Post Graduate Certificate in Teaching and Learning in Higher Education at ENU and is interested in improving the students learning experience.

\section{REFERENCES}

1. Benzies, A. (2011) EDU11114 - Assessment, Evaluation and Support - Module Handbook.

2. Biggs,J. (1999). What the Student Does: teaching for enhanced learning. Higher Education Research \& Development, 19(1), 57-75. http://dx.doi.org/10.1080/0729436990180105.

3. Biggs, J. and Tang, C., (2007). Teaching for Quality Learning at University. Third Edition. Buckingham: The Society for Research into Higher Education and Open University Press.

4. Biggs, J., (2003). Teaching for quality learning at university. Second edition. Buckingham: The Society for Research into Higher Education and Open University Press.

5. Biggs, J. \& Tang, C., (2007). Teaching for Quality Learning at University. Third Edition. Buckingham: The Society for Research into Higher Education and Open University Press.

6. Black, P.J., Harrison, C. (2004). Science Inside the Black Box: Assessment for Learning in the Science Classroom.

7. Bloom, B. S. et al, (1964). Taxonomy of Educational Objectives: the classification of educational goals. Vol.2. London: Longman

8. Boud, D. (1986) Implementing student self assessment. Higher Education Research and Development Society of Australia. Green Guide No. 5.

9. Boud, D. (2000) Sustainable assessment: rethinking assessment for the learning society. Studies in Continuing Education, 22, 2, 151-167. http://dx.doi.org/10.1080/713695728

10. Boud, D., Cohen, R. and Sampson, J. (1999) Peer learning and assessment. Assessment and Evaluation in Higher Education, 24, 4, 413-426. http://dx.doi. org/10.1080/0260293990240405

11. Boud, D., \& Feletti, G. (1997) The challenge of problem-based learning. (2nd ed.) London: Kogan Page.

12. Brown, S and Knight, P. (1994), Assessing Learners in Higher Education. London: Kogan Page.

13. Brown, S. (2004-2005) Assessment for learning. Learning and Teaching in Higher Education, 1, 81-89.

14. Brown, G.; Bull, J. and Pendlebury, M. (1997) Assessing student learning in higher education. London:Routledge.

15. Chambers, E. (1992) Workloads and the quality of student learning. Studies in Higher Education, 17, 2, 141-154. http://dx.doi.org/10.1080/03075079212331382627

16. Cox, K. R. (1976) How did you guess? Or what do multiple choice questions measure? Medical Journal of Australia, 1, 884-886.

17. Cowan, J., (1998). On Becoming an Innovative University Teacher. Buckingham: The Society for Research into Higher Education and Open University Press.

18. Crooks, T.J. (1988). The Impact of Classroom Evaluation Practices on Students. Review of 
Educational Research, 58(14), 438-481. http://dx.doi.org/10.3102/00346543058004438

19. Cuseo, J. (1992) Cooperative learning: A pedagogy for diversity. Cooperative Learning \& College Teaching, 3, 1, 2-6.

20. De Wilde, P and Pilkington, B. (2006) Education in environmental construction at the University of Plymouth: the Eco-House Project. Proceedings of PLEA2006 - The $23^{\text {rd }}$ Conference of Passive and Low Energy Architecture, Geneva, Switzerland. September 2006, 773-778.

21. Edinburgh Napier University. (2009). How was the Edinburgh Napier Graduate Attributes model developed? Retrieved July 19, 2015, from http://staff.napier.ac.uk/services/sas/student_development/EnhancingtheCurriculum/graduate_attributes/Pages/Howwasthemodeldeveloped.aspx

22. Edinburgh Napier University (2010) Learning, Teaching and Assessment Strategy: 20102015. Available at: http://staff.napier.ac.uk/services/academicdevelopment/LTA/Documents/LTA\%20STRATEGY\%202010-2015\%20WEB.pdf. Last accessed: 08/07/13.

23. Edinburgh Napier University (2011a) Effective Learning and Teaching in Higher Education Contexts Module Handbook.

24. Edinburgh Napier University - ENU (2011 b) Edinburgh Napier University Strategy 2015 - Summary of Key Performance Indicators. Available at: http://staff.napier.ac.uk/services/ secretary/governance/govman/court/Documents/chair/Edinburgh\%20Napier_KPI\%20 Summary 20111114.pdf. Last accessed: 24/02/12

25. Edinburgh Napier University (2012a) Assessment Handbook: An integrative approach to enhancing our practice, October 2012.

26. Edinburgh Napier University (2012b) University Quality Framework Section1: the approval of modules and programmes. Available at: http://staff.napier.ac.uk/services/sas/ academic quality/ExternalExaminersArchive/Documents/Approval $\% 20$ procedure $\% 20$ 2012-13\%20\%28updated\%20Aug\%2012\%29.pdf. Last accessed: 08/07/13

27. Edinburgh Napier University (2013) Guidance for completing the Module Descriptor. Available at: http://staff.napier.ac.uk/services/sas/academic_quality/QualityFramework/ Pages/Approvals.aspx. Last accessed: 08/07/13

28. Falchikov, N. (2002) In: Assessment: Case-studies, experience and practice from higher education Eds. Schwartz, P. and Webb, G. Chapter 9: 'Unpacking' Peer Assessment. London: KoganPage.

29. Garnier, C. (2011) Part 3: Module Descriptor Critique. EDU11105 Module 1: Effective Learning and Teaching in Higher Education Contexts.

30. Gibbs, G. (1992) Improving the quality if student learning. Bristol: Technical and Educational Services.

31. Gibbs, G. (2006) In: Innovative Assessment in Higher Education Eds. Bryan C. \& Klegg K. Chapter 2: How assessment frames student learning. Abingdon: Routledge

32. Gibbs, G; Habeshaw, S. and Habeshaw, T. (1992) 53 interesting ways to teach large classes. Fourth edition. Bristol: Technical and Educational Services.

33. Higher Education Academy. (2011). Assessment Audit Tool. Retrieved March 2, 2015, from https://www.heacademy.ac.uk/resource/assessment-audit-tool

34. Hounsell, D. (2003). Student feedback, learning and development. , 67-78. Higher education and the lifecourse.

35. Johnstone, A. H. and Ambusaidi, A. (2000) Fixed response: what are we testing? Chemistry Education: Research and Practice in Europe, 1, 3, 323-328. http://dx.doi.org/10.1039/ b0rp90014a

36. Juwah, C., Macfarlane-Dick, D., Matthew, B., Nicol, D., Ross, D., Smith, B., . (2004). Enhancing student learning through effective formative feedback. Retrieved from http:// ctlt.illinoisstate.edu/downloads/modules/design/enhancing_learning-through_formative_
Evaluation of

Assessment

Method to

Incorporate

Graduate Attributes

in Building

Surveying Module 
Chowdhry, S. Garnier, C. feedback.pdf

37. Kelvin H. K. Tan,K.H.K., Prosserc,M. (2004). Qualitatively different ways of differentiating student achievement: a phenomenographic study of academics' conceptions of grade descriptors. Assessment \& Evaluation in Higher Education, 29(3), 267-282. http://dx.doi. org/10.1080/0260293042000188230

38. Keppell, M., \& Carless, D. (2006). Learning-oriented assessment: A technology based case study. Assessment in Education, 13(2), 179-191. http://dx.doi. org/10.1080/09695940600703944

39. Klegeris, A., Hurren, H. (2011). Impact of problem-based learning in a large classroom setting: student perception and problem-solving skills. Advances in Physiology Education, 35(4), 408-415. http://dx.doi.org/10.1152/advan.00046.2011

40. Kneale, P. And Collins, C. (1996) Study Skills for Psychology. London: Arnold.

41. Kolb, D. A., (1984). Experiential Learning: experience as the source of learning and development. New Jersey: Prentice Hall.

42. Lindberg-Sand,A., \& Olsson,T. (2008). Sustainable assessment? Critical features of the assessment process in a modularised engineering programme. International Journal of Education Research, 47(1), 165-174. http://dx.doi.org/10.1016/j.ijer.2008.01.004

43. London: Kogan Page. Supporting Student Learning: Case Studies, Experience, and Practice from Higher Education (2002).

44. McDowell, L., Wakelin, D., Montgomery, C., King, S. (2011). Does assessment for learning make a difference? The development of a questionnaire to explore the student response. Assessment \& Evaluation in Higher Education, 36(7), 749-765. http://dx.doi.org/10.1080 /02602938.2010.488792

45. Miller, N. (2002). Alternative forms of formative and summative assessment. The Handbook for Economics Lecturers. Online: http://www.economicsnetwork.ac.uk/handbook/ assessment. Last Accessed: 03/07/2013.

46. Nicol, D.(2007) E-assessment by design: using multiple-choice tests to good effect. Journal of Further and Higher Education, 31, 1, 53-64. http://dx.doi.org/10.1080/03098770601167922

47. Nicol, D. J. \& Macfarlane-Dick, D. (2006) Formative assessment and self-regulated learning: a model and seven principles of good feedback practice. Studies in Higher Education, 31, 2, 198-218. http://dx.doi.org/10.1080/03075070600572090

48. Pan, W., Murray, P, Cotton, D. and Garmston, H. (2012) Integrating research-informed teaching into sustainable construction education. Journal for Education in the Built Environment, 7, 1, 94-117. http://dx.doi.org/10.11120/jebe.2012.07010094

49. Quality Assurance Agency for Higher Education (2006). Code of practice for the assurance of academic quality and standards in Higher Education: Assessment of Students. Online: http://www.qaa.ac.uk/Publications/InformationAndGuidance/Pages/Code-ofpractice-Section-6.aspx. Last Accessed: 03/07/2013.

50. Quality Assurance Agency for Higher Education (2007). Integrative Assessment: blending assignments and assessments for high quality learning. Guide No. 3.

51. Ramsden, P., (2003). Learning to Teach in Higher Education. London: Routledge Falmer.

52. Roberts, A. (2007) Problem based learning in architecture. CEBE Briefing Guide No. 11. Cardiff: Centre for Education in the Built Environment.

53. Rodriguez, L. and Francisco Cano, F. (2007) The learning approaches and epistemological beliefs of university students: A cross-sectional and longitudinal study. Studies in Higher Education, 32, 4, 647-667. http://dx.doi.org/10.1080/03075070701573807

54. Sadlo, G. And Richardson J.T.E. (2003) Approaches to studying and perceptions of the academic environment in students following problem based and subject based curricula. Higher Education Research and Development, 22, 253-274. http://dx.doi. org/10.1080/0729436032000145130 
55. Scouller, K. (1998) The influence of assessment method on students'learning approaches:multiple choice question examination versus assignment essay. Higher Education, 35, 453-472. http://dx.doi.org/10.1023/A:1003196224280

56. Segers, M. and Dochy, F. (2001) New assessment forms in problem-based learning: the value-added of the students' perspective. Studies in Higher Education, 26, 3, 327-343. http://dx.doi.org/10.1080/03075070120076291

57. Schmidt, N.; Norman, G. and Boshuzen, H. (1990) A cognitive perspective on medical expertise: Theory and Implications. Academic medicine, 65, 611-621. http://dx.doi. org/10.1097/00001888-199010000-00001

58. Struyven,K., Dochy,F., \& Janssens,S. (2005). Studentss' perceptions about evaluation and assessment in higher education: a review. Assessment and Evaluation in Higher Education, 30(4), 331-347. http://dx.doi.org/10.1080/02602930500099102

59. Teixeira-Dias, José J.C., Jesus, H.P., Souza, F.N., and Watts,M. (2005). Teaching for quality learning in chemistry. International Journal of Science Education, 27(9), 1123-1137. http://dx.doi.org/10.1080/09500690500102813

60. The Higher Education Academy (2011) Assessment Audit Tool - Centre for Bioscience. Online: http://www.bioscience.heacademy.ac.uk/ftp/resources/audit/assessment.pdf Last accessed: 03/07/2013.

61. The Higher Education Academy (2011) Employability Audit Tool - Centre for Bioscience. Online: http://www.bioscience.heacademy.ac.uk/ftp/resources/audit/employability.pdf Last accessed: 03/07/2013.

62. University of Reading (2013) Assessing large numbers of students. Available at: http:// www.reading.ac.uk/engageinassessment/assessing-large-groups/eia-assessing-largegroups.aspx. Last accessed: 25/06/13.

63. Wood, D.F. (2003) ABC of learning and teaching in medicine: problem-based learning. British Medicine Journal, 326, 328-330. http://dx.doi.org/10.1136/bmj.326.7384.328

64. Zakrzewski, S. and Bull, J. (1998) The mass implementation and evaluation of computer-based assessments. Assessment and Evaluation in Higher Education, 23, 2, 141-152. http://dx.doi.org/10.1080/0260293980230203.

Evaluation of

Assessment

Method to

Incorporate

Graduate Attributes

in Building

Surveying Module 
Chowdhry, S. Garnier, C.

\section{APPENDICES}

APPENDIX I - STUDENT SURVEYS

\section{Student Questionnaire - Sustainable Development: BSV10104}

Stage 1

1. How would you rate your understanding of sustainable development on a scale from 1 to 5 ( $5=\mathrm{V}$.Good, $1=\mathrm{V} . \mathrm{Bad})$ ?

2. Define, on your opinion, what is sustainable development

3. Using bullet points identify where, in your opinion, Sustainable Development fits within your programme of study.

4. What are your aspirations by undertaking this module?

5. Please write down which programme you are studying:

\section{Student Questionnaire - Sustainable Development: BSV10104}

Stage 2

1. Being in the middle of the Trimester, how would you rate your understanding of sustainable development on a scale from 1 to $5(5=\mathrm{V}$.Good, $1=\mathrm{V}$. Bad)?

2. How would you rate this Module so far with respects to:

CONTENTS (please circle your answer)

Very Good Good Bad Very Bad Average

Please comment:

CHALLENGES (Reflection and Research Activities)

Very Good Good Bad Very Bad Average

Please comment:

TIME (to undertake activities)

Very Good Good Bad Very Bad Average

Please comment:

RELEVANCE / ALIGNMENT WITH OTHER MODULES

Very Good Good Bad $\quad$ Very Bad Average

Please comment:

1. Reflecting on the previous questionnaire filled, how would you rate, at this stage, the relevance of sustainable development within your programme of study:

Very relevant Relevant Not Relevant 
If not relevant, please comment:

2. On a scale from 1 to 5 , rate how the module is currently meeting your aspirations $(5=\mathrm{V}$.Well, $1=\mathrm{V} . \mathrm{Bad})$ :

Please comment

3. Please write down which programme you are studying:

Student Questionnaire - Sustainable Development: BSV10104 Stage 3

1. Having finished the BSV10104-Sustainable Development module, how would you rate your understanding of sustainable development on a scale from 1 to $5(1=\mathrm{V} . \mathrm{Bad}, 5=\mathrm{V}$.Good - please circle your answer $)$ ?
1
2
3
4
5

3. How would you rate this Module with respects to:

CONTENTS (please circle your answer)

Very Good Good Bad Very Bad Average

Please comment:

CHALLENGES (Reflection, Research Activities, Revision Lecture, Exam)

Very Good Good Bad Very Bad Average

Please comment:

TIME (to undertake activities with other curriculum activities)

Very Good Good Bad Very Bad Average

Please comment:

1. How would you rate the relevance of the sustainable development module within your programme of study:

Very relevant Relevant Not Relevant

If still not relevant, please comment:

2. Using bullet points identify areas you would have liked to be covered in this module to make it more relevant to your course and cohort as a whole.

3. On a scale from 1 to 5 , rate how the module has met your aspirations 
Chowdhry, S.

$(1=\mathrm{V} . \mathrm{Bad}, 5=\mathrm{V} . \mathrm{Good}$ - please circle your answer $)$ ?

Garnier, C.

12

3

4

5

Please comment

4. Identify ONE topic covered within the course that you would have liked to cover in more depth.

Please comment

5. In your opinion, was the assessment method used for this module adequate to test your knowledge. $(1=$ Not.Adequate, $5=$ V.Adequate $)$.

2

3

4

5

Please comment

6. Using the six definitions below please identify which, in your opinion, apply to the activities undertaken in the module. Please tick which apply.

Table 12: Learning cycle in relation to BSV10104 activities

\begin{tabular}{|c|c|c|c|}
\hline \multirow[t]{2}{*}{ Learning Cycle Categories } & \multicolumn{3}{|l|}{ Activities } \\
\hline & $\begin{array}{l}\text { Reflection } \\
\text { Activities }\end{array}$ & $\begin{array}{l}\text { Research } \\
\text { Activities }\end{array}$ & $\begin{array}{l}\text { Final } \\
\text { exam }\end{array}$ \\
\hline \multicolumn{4}{|l|}{$\begin{array}{l}\text { Knowledge (1) - Involves the recall of } \\
\text { specific facts and theories, methods and } \\
\text { processes. }\end{array}$} \\
\hline \multicolumn{4}{|l|}{$\begin{array}{l}\text { Comprehension (2) - Involves knowing } \\
\text { the information which is being commu- } \\
\text { nicated and being able to make use of the } \\
\text { material without relating it to other infor- } \\
\text { mation or seeing its fullest implications. }\end{array}$} \\
\hline \multicolumn{4}{|l|}{$\begin{array}{l}\text { Application (3) - Focuses on having stu- } \\
\text { dents apply what has been learned to differ- } \\
\text { ent situations and learning tasks, requiring } \\
\text { students to use information that they know } \\
\text { and understand. }\end{array}$} \\
\hline \multicolumn{4}{|l|}{$\begin{array}{l}\text { Analysis (4) - Involves breaking down the } \\
\text { information or situations and separating } \\
\text { them into their component parts, focusing } \\
\text { on the relationships of these parts with each } \\
\text { other and with the whole structure. }\end{array}$} \\
\hline Learning Cycle Categories & \multicolumn{3}{|l|}{ Activities } \\
\hline
\end{tabular}


Synthesis (5) - Focuses on the combination of learned elements and parts to form a new whole. This includes working with pieces and elements and arranging them so as to create a new form, pattern or structure of the information.

Evaluation (6) - Involves making judgments about the value of material and methods for given purposes. Judgments are made based on standards or criteria, either established by and provided for the student or those determined by the student.

\begin{tabular}{|l|l|l|l|}
\hline & & \\
\hline & & \\
\hline & & \\
\hline
\end{tabular}

1. Finally, please identify, in your opinion, which of the same six definitions above, would apply to the activities listed in Table 2 below if they were to be implemented in your course. Please input the number associated to the definition against the listed activity.

Table 13: Learning Cycle and Activities

\begin{tabular}{|l|l|}
\hline \multicolumn{1}{|c|}{\begin{tabular}{rl|} 
Activities \& Assessment \\
methods
\end{tabular}} & $\begin{array}{l}\text { Learning cycle categories } \\
\text { 1: Knowledge 2: Comprehension } \\
\text { 3: Application 4: Analysis } \\
\text { 5: Synthesis 6: Evaluation }\end{array}$ \\
\hline Problem Based Learning report & \\
\hline Individual Written report & \\
\hline Group Written report & \\
\hline Individual Presentations & \\
\hline Group Presentations & \\
\hline Poster Presentations & \\
\hline Quizzes & \\
\hline Midterm exams & \\
\hline Final exam & \\
\hline
\end{tabular}

1. In your opinion, would you agree or disagree that an additional form of assessment should be included in this module? Please circle your answer

\begin{tabular}{|l|l|l|l|l|}
\hline $\begin{array}{l}\text { Strongly } \\
\text { Agree }\end{array}$ & Agree & Disagree & Strongly Disagree & $\begin{array}{l}\text { Neither } \\
\text { agree or } \\
\text { disagree }\end{array}$ \\
\hline
\end{tabular}

If you agree, in your opinion, which type of assessment would be most suitable: 
Chowdhry, S. If disagree, please comment:

Garnier, C.

1. Identify ONE topic covered within the Sustainable Development module that you would have liked to cover in more depth, and undertake a CWon.

2. Considering the work-load you had in other modules taught in TR1, would you agree or disagree that you would have had the time to undertake a $\mathrm{CW}$ within the Sustainable Development Module. Please circle your answer.

\begin{tabular}{|l|l|l|l|l|}
\hline $\begin{array}{l}\text { Strongly } \\
\text { Agree }\end{array}$ & Agree & Disagree & Strongly Disagree & $\begin{array}{l}\text { Neither agree or } \\
\text { disagree }\end{array}$ \\
\hline
\end{tabular}

If you disagree, please comment:

Could an integration of the sustainable development module be possible with other modules taught in TR1? Please circle YES / NO

If so, please specify which module and how you would see the integration happening. 


\section{APPENDIX II AUDIT TOOLS AND CHECKLIST PRE AND POST CHANGES}

\section{Assessment Audit Tool}

Evaluation of

Assessment

Method to

Incorporate

Graduate Attributes

in Building

Surveying Module

\section{What is an Audit Tool?}

An Audit Tool is a good way to initiate discussion and development on an issue. It enables you to make clear the range of activities which may contribute to the issue and the process can reassure colleagues that quite a lot of work may already be developed in the area. The process can also recognise local autonomy and priorities, within an institutional frame-work, and can:

- encourage development of a strategic plan to clarify how assessment practices can be developed;

- identify how far and in what area development should take place; and

- give recognition to existing activity which contributes effectively.

However an Audit also serves broader purposes:

- raising awareness by staff of practice in general and of the institution's plans;

- revealing or clarifying links between the aspect being audited and plans and strategies in other areas;

- engaging a wider constituency within the academic community; and

- facilitating dialogue and development within and between teaching units.

The purpose of this Audit is developmental, not simply to come up with an overall score for the course. It is designed to help teachers consider the content and design of a course with respect to the issue of assessment and to see where they could improve the course to better address this issue.

\section{The Assessment Audit Tool can be downloaded from the Centre's website: \\ www.bioscience.heacademy.ac.uk/resources/audit.aspx}

The Assessment Audit Tool can be changed to suit your requirements. This audit tool was last updated in December 2011 
Chowdhry, S. Garnier, C.

\section{Are the assessment methods appropriate to the learning objectives?}

\begin{tabular}{|l|l|}
\hline & Score \\
\hline $\begin{array}{l}\text { Are the learning objectives (i.e. the changes in the student's knowledge, } \\
\text { skills and attitudes) explicit for the module and for each constituent element } \\
\text { piece of work where appropriate? }\end{array}$ & \\
\hline $\begin{array}{l}\text { Are the different types of element in the learning objectives reflected in the } \\
\text { assessment? (e.g. knowledge, understanding, skills, attitudes etc) }\end{array}$ & \\
\hline $\begin{array}{l}\text { In setting the learning objectives is consideration given to the learning } \\
\text { objectives in other concurrent or previous modules? }\end{array}$ & \\
\hline $\begin{array}{l}\text { Is the different achievement in each learning objective separately } \\
\text { identifiable by the student in the overall assessment? }\end{array}$ & \\
\hline $\begin{array}{l}\text { Are assessment methods / conditions adjusted appropriately for disabled } \\
\text { students? }\end{array}$ & \\
\hline $\begin{array}{l}\text { Do students experience the method of assessment before it is used } \\
\text { summatively? Either in this module or in a previous module? }\end{array}$ & \\
\hline $\begin{array}{l}\text { A single type of assessment (e.g. all MCQs) may disadvantage some } \\
\text { students. Are a variety of assessment methods used in different } \\
\text { circumstances? } \\
\text { (For example knowledge can be assessed using McQ, EMQ, SAQ, essays marked for } \\
\text { factual content etc. To what extent are different assessment techniques used to } \\
\text { give the student a variety of ways in which to demonstrate their abilities?) }\end{array}$ & \\
\hline
\end{tabular}

2. The assessment methods used - are they known to provide a secure assessment appropriate to the teaching style?

\begin{tabular}{|l|l|}
\hline & Score \\
\hline To what extent are the methods subjective? & \\
\hline Are assessments made from written and agreed marking schemes? & \\
\hline $\begin{array}{l}\text { If multiple markers are used is uniformity of marking tested and, if } \\
\text { necessary, compensated for? }\end{array}$ & \\
\hline $\begin{array}{l}\text { If double marked is there a mechanism other than taking the average to } \\
\text { resolve significant differences? }\end{array}$ & \\
\hline Is marking done anonymously? (If machine marked score 4) & \\
\hline $\begin{array}{l}\text { Are the assessment methods appropriate to the teaching style used? } \\
\text { in.g. If the course is primarily taught using problem-based-learning it would be } \\
\text { factual knowledge.) }\end{array}$ & \\
\hline $\begin{array}{l}\text { Are known mark sets included in the mark spread sheets to demonstrate } \\
\text { accuracy of mathematical processing / combining of marks? }\end{array}$ & \\
\hline Is there external input into the assessment process? & \\
\hline
\end{tabular}

The Assessment Audit Tool developed by lan Hughes and the team at the UK. Centre for Bioscience, University of Leeds is licensed under aCreative Commons AttributionNonCommercial ShareAlike 3.0 Unported License. Based on a work atwww. bioscience heacademy. ac. uk. 


\section{Is the assessment set-up to reduce plagiarism?}

\begin{tabular}{|l|l|}
\hline Are students clear as to what would be deemed to constitute plagiarism? & Score \\
\hline Are students aware of the penalties, if they are caught plagiarising work? & \\
\hline Have assessments been designed to reduce plagiarism by: & $-\cdots$ \\
\hline Changing the assessment from year to year? & \\
\hline $\begin{array}{l}\text { Requesting evidence of how students completed coursework (e.g. by } \\
\text { collecting plans, drafts, field or lab notes)? }\end{array}$ & \\
\hline $\begin{array}{l}\text { Setting work that could not easily be copied from the internet or } \\
\text { books, either because of the format requested (e.g. poster / oral } \\
\text { presentation rather than essay) or by asking for a critique of set texts } \\
\text { rather than just describing a theory? }\end{array}$ & \\
\hline
\end{tabular}

\section{Are published marking criteria and grade descriptors available to} students?

\begin{tabular}{|l|l|}
\hline & Score \\
\hline Are there grade descriptors available to the students? & \\
\hline Are these known to and followed by the staff doing the marking? & \\
\hline Are there exemplar answers? & \\
\hline Are exemplar answers available at different grades? & \\
\hline $\begin{array}{l}\text { Are the grade descriptors congruent with those on other modules taken by } \\
\text { the students? }\end{array}$ & \\
\hline
\end{tabular}

\section{How is the pass mark decided? Peer or criterion referenced?}

(Peer referenced is where the pass mark / grade boundaries are defined in the light of the actual achievement of the student body as a whole. Criterion referenced is where these are decided independently of the actual achievement of the student body.) If peer referenced deduct 1 from each score.

\begin{tabular}{|l|l|}
\hline & Score \\
\hline Is the mark distribution for each piece of work known and considered? & \\
\hline $\begin{array}{l}\text { Is the distribution of marks in the module compared with that of previous } \\
\text { year's cohorts? }\end{array}$ & \\
\hline $\begin{array}{l}\text { Is data available and used to compare the distribution of marks of a student } \\
\text { cohort in this module with that in other concurrent modules? }\end{array}$ & \\
\hline $\begin{array}{l}\text { Is there external moderation of the marks? } \\
\text { across different modules? } \\
\text { If criterion referenced: does more than one person determine and agree the } \\
\text { grade boundaries? }\end{array}$ & \\
\hline
\end{tabular}

The Assessment Audit Tool developed by lan Hughes and the team at the UK Centre for Bioscience, University of Leeds is licensed under a Creative Commons AttributionNonCommercial-ShareAlike 3.0 Unported License. Based on a work atwrww. bioscience heacademy. ac.uk.
Evaluation of

Assessment

Method to

Incorporate

Graduate Attributes

in Building

Surveying Module 
Chowdhry, S. Garnier, C.

\section{Is assessment timely and progressive throughout the course?}

\begin{tabular}{|c|c|}
\hline & Score \\
\hline $\begin{array}{l}\text { Does assessment provide a monitor of student performance throughout the } \\
\text { module? }\end{array}$ & \\
\hline $\begin{array}{l}\text { Is there time to allow students to respond to a poor assessment before the } \\
\text { end of the module? }\end{array}$ & \\
\hline Is assessment timely: & - \\
\hline With regard to the speed with which results are available to students? & \\
\hline $\begin{array}{l}\text { In relation to other assessed work on the module? (So students know } \\
\text { the results and have had feedback before the next piece of assessed } \\
\text { work?) }\end{array}$ & \\
\hline $\begin{array}{l}\text { In relation to other assessment on other modules? (So the totality of } \\
\text { the assessment as experienced by the students is reasonably } \\
\text { distributed and does not all take place in an unreasonably short } \\
\text { period.) }\end{array}$ & \\
\hline $\begin{array}{l}\text { In relation to other commitments staff may have? (So they are not } \\
\text { overloaded with marking.) }\end{array}$ & \\
\hline
\end{tabular}

\section{Feedback}

\begin{tabular}{|l|l|}
\hline & Score \\
\hline Is feedback provided for all assessments mid-course? & \\
\hline Is feedback provided for the end of module assessment? & \\
\hline Is feedback provided to all students? & \\
\hline $\begin{array}{l}\text { Is feedback sufficiently detailed to enable students to identify particular } \\
\text { weaknesses? }\end{array}$ & \\
\hline Is feedback provided on omissions as well as errors? & \\
\hline Do you know that all students access the feedback provided? & \\
\hline Are students performing poorly counselled on a one-to-one basis? & \\
\hline Does counselling take into account performance on other modules? & \\
\hline
\end{tabular}




\begin{tabular}{|l|l|}
\hline & Score \\
\hline $\begin{array}{l}\text { Are these arrangements written, available to students and explicit with } \\
\text { regard to format and material covered? }\end{array}$ & \\
\hline $\begin{array}{l}\text { Are the dates / times of any re-sit exams known to the students at least } 3 \\
\text { months before it takes place? }\end{array}$ & \\
\hline Are the learning objectives the same? & \\
\hline Are re-sit candidates given effective feedback on their first performance? & \\
\hline
\end{tabular}

9. What are students' views on the quality and usefulness of the assessment?

\begin{tabular}{|l|l|}
\hline & Score \\
\hline $\begin{array}{l}\text { Are students' views on the assessment processes known and elicited each } \\
\text { year? }\end{array}$ & \\
\hline $\begin{array}{l}\text { Is this data obtained from all students other than those absent due to } \\
\text { illness? }\end{array}$ & \\
\hline $\begin{array}{l}\text { Are students treated as a homogeneous group (score 1) or are their views } \\
\text { fragmented into those of the various sub-groups making up the student } \\
\text { body? (score 4) (e.g. Levels } 1 \text { and } 2 \text { taking the same module? Students on } \\
\text { different courses but taking the same module? If the students are a } \\
\text { homogeneous group (i.e. all taking the same courses / modules) score 4.) }\end{array}$ & \\
\hline
\end{tabular}

This section of the Audit Tool looks at the proportion of total teaching time allocated to assessment. It is appreciated that individual students will spend different amounts of time involved with teaching / learning / assessment activities. Use estimated average values.

\begin{tabular}{|c|c|}
\hline \multirow[b]{2}{*}{$\begin{array}{l}\text { a) Total hours spent by teachers (including demonstrators, PG tutors etc) } \\
\text { on assessment in this module. This includes time spent setting } \\
\text { assessments, marking student work, compiling and processing assessment } \\
\text { data, marking lab / project work (include that proportion of time spent in } \\
\text { labs which is actually involved in assessing the performance of the student } \\
\text { at the bench if this is done). }\end{array}$} & Hours \\
\hline & \\
\hline $\begin{array}{l}\text { b) Total hours of teaching time spent by staff in direct contact with } \\
\text { students. This is usually time-tabled time for teachers (of all levels) to be } \\
\text { in contact with students. If students are taught for } 1 \text { hour in, say, } 5 \text { small } \\
\text { groups, then } 5 \text { hours of teacher time would be involved. Do NOT include } \\
\text { preparation time or time spent on assessment of students. }\end{array}$ & \\
\hline $\begin{array}{l}\text { c) Total hours spent by a student in being assessed. Include examination } \\
\text { and viva time, time spent actually writing assessed course work (e.g. } \\
\text { essays, practical write-ups etc) but not the time spent preparing the } \\
\text { material. Estimate where necessary. Assume course work takes } 0.5 \text { hr to } \\
\text { write } 1 \text { page. }\end{array}$ & \\
\hline $\begin{array}{l}\text { d) Total hours for which a student is involved in any form of teaching / } \\
\text { learning / assessment activity (lectures }+ \text { practicals }+ \text { self-directed }+ \\
\text { directed }+ \text { tutorials }+ \text { others etc.) on this module. This is the total hours } \\
\text { you would expect this module and the work associated with it to occupy } \\
\text { the student. Estimate where necessary. }\end{array}$ & \\
\hline $\begin{array}{l}\text { e) How proportional is the staff time spent in assessment to the marks } \\
\text { awarded? How proportional is the student time spent in completing the } \\
\text { work for an assessment to the marks awarded? (For each assessed item } \\
\text { consider the proportionality between the fraction of the total marks } \\
\text { awarded and the assessment time devoted to it. Consider this for both } \\
\text { staff and students. This item is not represented numerically but you should } \\
\text { note areas where the time spent by staff in completing the assessment is } \\
\text { very large compared with the proportion of marks given for the work.) }\end{array}$ & $\cdots$ \\
\hline
\end{tabular}

Evaluation of

Assessment

Method to

Incorporate

Graduate Attributes

in Building

Surveying Module 
Chowdhry, S.

Garnier, C.

Action Plan

Make a note of the resources you will need and whose help will be required.

1.

2.

3.

4. 


\section{Employability Audit Tool}

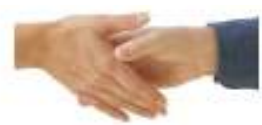

\section{What is an Audit Tool?}

An audit tool is a good way to initiate discussion and development on an issue. It enables you to make clear the range of activities which may contribute to the issue and the process can reassure colleagues that quite a lot of work may already be developed in the area. The process can also recognise local autonomy and priorities, within an institutional frame-work, and can:

- encourage development of a strategic plan to clarify how employability can be developed in relation to a particular discipline;

- identify how far and in what area development should take place;

- give recognition to existing activity which contributes effectively.

However an audit tool also serves broader purposes:

- raising awareness by staff of practice in general and of the institution's plans;

- revealing or clarifying links between the aspect being audited and plans and strategies in other areas;

- engaging a wider constituency within the academic community; and

- facilitating dialogue and development within and between teaching units.

The purpose of this Audit is developmental, not simply to come up with an overall score for the course. It is designed to help teachers consider the content and design of a course with respect to the issue of employability and to see where they could improve the course to better address this issue.

\section{The Employability Audit Tool can be downloaded from the Centre's} website:

www.bioscience.heacadeny.ac.uk/resources/audit.aspx

The Employability Audit Tool can be changed to suit your requirements. This audit tool was last updated in December 2011
Evaluation of

Assessment

Method to

Incorporate

Graduate Attributes

in Building

Surveying Module 
Chowdhry, S. Garnier, C.

\section{Graduate employment}

\begin{tabular}{|l|l|}
\hline & Score \\
\hline Do academic staff know who actually employs your graduates? & \\
\hline $\begin{array}{l}\text { Has graduate employment destination data been circulated to academic staff } \\
\text { within the last } 2 \text { years? }\end{array}$ & \\
\hline Do current students know who employs graduates from this course? & \\
\hline Do recent graduates visit to talk about their current jobs? & \\
\hline $\begin{array}{l}\text { Are students made aware of where they can obtain information on graduate } \\
\text { destinations in employment? }\end{array}$ & \\
\hline $\begin{array}{l}\text { Are students aware at an early stage of the employment opportunities open } \\
\text { to them? }\end{array}$ & \\
\hline
\end{tabular}

\section{Career-path development}

\begin{tabular}{|l|l|}
\hline & Score \\
\hline $\begin{array}{l}\text { Are visitors giving research talks encouraged to reveal their own career } \\
\text { paths? }\end{array}$ & \\
\hline Are graduate career profiles available to students? & \\
\hline Do recent graduates visit to talk about their career paths? & \\
\hline Do more senior graduates visit to talk about their career paths? & \\
\hline Are students explicitly taught career management skills? & \\
\hline
\end{tabular}

\section{Relationships with employers}

\begin{tabular}{|l|l|}
\hline \multicolumn{1}{|l|}{\begin{tabular}{l|} 
Have you made potential employers aware of the skills your students \\
develop?
\end{tabular}} & Score \\
\hline $\begin{array}{l}\text { Is your institution / unit on the list of favoured institutions with important } \\
\text { employers? }\end{array}$ & \\
\hline $\begin{array}{l}\text { Do you know what employers perceive to be the strengths and weaknesses } \\
\text { of your students? }\end{array}$ & \\
\hline Do students have the opportunity to visit local employers? & \\
\hline Do you have good communication with major employers of your graduates? & \\
\hline Do employers visit your unit to give talks about employment opportunities? & \\
\hline Do employers attend any student final year project presentations? & \\
\hline $\begin{array}{l}\text { Do you know what skills, knowledge and attitudes your major employers see } \\
\text { as becoming more important in the next } 4 \text { years? }\end{array}$ & \\
\hline
\end{tabular}

The Emplayabality Audit Tool developed by lan Hughes and the team af the UK Centre for Bioscience, University of Leeds is licensed under a Creative Commons AttributionNNonCommercial ShareAlike 30 Unported License.

Based on a work atwww bioscience heacademy acuk. 


\section{Options for work experience}

\begin{tabular}{|l|l|}
\hline & Score \\
\hline Are work experience opportunities provided / encouraged during vacations? & \\
\hline Are sandwich placements provided / encouraged as part of the course? & \\
\hline Are overseas placements possible and encouraged for students? & \\
\hline Are realistic simulations used to give experience of real work situations? & \\
\hline $\begin{array}{l}\text { Do some students carry out course project work in real settings with } \\
\text { employers? }\end{array}$ & \\
\hline $\begin{array}{l}\text { Are work placements available in areas not involving your specific discipline? } \\
\text { What proportion of students on your course have obtained work experience } \\
4=>50 \% \text { ) }\end{array}$ & \\
\hline $\begin{array}{l}\text { Are students on work placements supported by a process which encourages } \\
\text { reflection and emphasises breadth of learning opportunities? }\end{array}$ & \\
\hline
\end{tabular}

\section{Does your curriculum promote employability?}

\begin{tabular}{|l|l|}
\hline & Score \\
\hline Do you know specifically what employers are looking for in graduates? & \\
\hline $\begin{array}{l}\text { Have employers reviewed your curriculum and provided feedback on its } \\
\text { content? }\end{array}$ & \\
\hline Are generic skills (e.g. communication, group working, IT) explicitly taught? & \\
\hline Are generic skills assessed? & \\
\hline Is there a skills matrix which is completed by each student? & \\
\hline Are subject-specific skills taught and practiced? & \\
\hline \begin{tabular}{l} 
Are subject-specific skills assessed? \\
\hline Can you detect any of your students who are not numerate?
\end{tabular} & \\
\hline \begin{tabular}{l} 
Do you assess ability to write clear, concise, correct English? \\
statement incorporated in your curriculum? \\
www.qaa.ac.uk/academicinfrastructure/benchmark/ \\
/ interests? \\
\hline $\begin{array}{l}\text { Do students have a choice of modules or choice of work areas within a } \\
\text { students? }\end{array}$
\end{tabular} & \\
\hline
\end{tabular}

The Employability Audit Tool developed by lan Hughes and the team at the UK Centre for Bioscience, University of Leeds is licensed under a Creative Commons AttributionNonCommercial ShareAlike 3.0 Unported License. Based an a work atwww. bicscience heacademy. acuk.
Evaluation of

Assessment

Method to

Incorporate

Graduate Attributes

in Building

Surveying Module 
Chowdhry, S. Garnier, C.
5. Does your curriculum promote employability? (cont.)

\begin{tabular}{|l|l|}
\hline & Score \\
\hline $\begin{array}{l}\text { Have you identified where work related learning activities take place in the } \\
\text { course and are these made explicit to students? }\end{array}$ & \\
\hline $\begin{array}{l}\text { Have opportunities to increase work related learning in the course been } \\
\text { identified and taken? }\end{array}$ & \\
\hline Are all students given a basic grounding in ethics within the discipline field? & \\
\hline
\end{tabular}

\section{Are students helped in obtaining and developing careers?}

\begin{tabular}{|l|l|}
\hline & Score \\
\hline Is a 'Record of Achievement' maintained throughout the course? & \\
\hline $\begin{array}{l}\text { Is reflection on and review of achievements actively promoted within the } \\
\text { course? }\end{array}$ & \\
\hline Do students get help with producing / improving a CV? & \\
\hline Do students get help with letters of application for employment? & \\
\hline Is help with module choice available in each year? & \\
\hline
\end{tabular}

\section{Extra-curricula activity}

\begin{tabular}{|l|l|}
\hline & Score \\
\hline $\begin{array}{l}\text { Is the contribution of extra-curricula activity to CV and skills development } \\
\text { explained to students early in the course? }\end{array}$ & \\
\hline Are extra-curricula activities and responsibilities recorded by your students? & \\
\hline Are extra-curricula activities known to staff (e.g. personal tutors)? & \\
\hline Are arrangements in place to encourage voluntary work by students? & \\
\hline
\end{tabular}

\section{General}

\begin{tabular}{|l|l|}
\hline & Score \\
\hline $\begin{array}{l}\text { Is there an effective relationship between the course team and your Careers } \\
\text { Service? }\end{array}$ & \\
\hline $\begin{array}{l}\text { Are students explicitly guided in the course to make contact with the Careers } \\
\text { Service? }\end{array}$ & \\
\hline Do you know the name of the Careers Adviser associated with your subject? & \\
\hline Are your students encouraged to have confidence and high aspirations? & \\
\hline
\end{tabular}

The Employability Audit Tool developed by lan Hughes and the team at the UK Centre for Bioscience, University of Leeds is licensed under a Creative Commons AttributionNonCommercial Share/Nike 3.0 Unported License. Based on a work atwrw bioscience heacademy. acuk 


\section{General (cont.)}

Do staff generally have access to full information about a student's in-course and extra-curricula performance (e.g. student's CV) when writing references?

Have you considered employability in the context of widening participation?

Have you considered employability in the context of disability?

Have you considered employability in the context of ethnicity?
Evaluation of

Assessment

Method to

Incorporate

Graduate Attributes in Building

Surveying Module 
Chowdhry, S. Garnier, C.
Action Plan

Make a note of the resources you will need and whose help will be required.

1.

2.

3.

4.

The Emplayability Audit Tool developed by lan Hughes and the team at the LXK Centre for Biosciencan, University of Leeds is licensed under a Creative Commons Attritution NonCommercial ShareAlike 30 Unported Lieense

Based an a wokk atwww.bioscience.heacartemy.acuk. 


\section{Appendix 7}

\section{Module evaluation checklist}

This checklist should be completed prior to the first time a module is implemented in blended or fully online format, as part of the quality assurance procedures for blended and online delivery that are described in the Quality Framework (for the definition of a blended module see section $A 9$ ). The criteria within this checklist correspond to the main tenets of good practice described in this guide, which are expanded upon more fully in the Edinburgh Napier publication Pedagogy and learning technology: a practical guide.

This checklist should be used in an independent review of a blended or online module to be conducted by an Academic Development Adviser (ADA) Online Leaming who has not been involved in the development of the module, or by an appropriately experienced tutor or reviewer from outwith the module team. In addition, the checklist can serve as a reference to module developers during the online module design and development stage.

It is not expected that all criteria are met for all modules. Fully online modules should meet the majority of the criteria. It is left to the discretion of the knowledgeable reviewer which criteria to fulfil.

Instructions to reviewer. please tick the appropriate box against each of the criteria provided, and write any additional comments or recommendations you have in the space provided. If NAA has been selected please explain why. Return checklist to module leader who can seek additional support and guidance from the faculty's Academic Development Adviser (ADA) Online Learning. Please remember to sign and date this form.

Module title:

Reviewed by:

Evaluation of

Assessment

Method to

Incorporate

Graduate Attributes

in Building

Surveying Module 
Chowdhry, S. Garnier, C.
1) Module material

\begin{tabular}{|l|cc|}
\hline Criteria & YES NO N/A \\
\hline Learning outcomes are stated wherever appropriate & $\square$ \\
\hline Subject material (in introductions, units) is clearly written & $\square$ \\
\hline $\begin{array}{l}\text { Subject material is written inclusively (eg culturally biased terms and } \\
\text { examples are avoided wherever possible) }\end{array}$ & $\square$ \\
\hline $\begin{array}{l}\text { The structure and organisation of the module (eg dates and deadlines, } \\
\text { the sequence of events) is explicitly stated }\end{array}$ & $\square$ \\
\hline Full details of all core texts and resources are provided & $\square$ \\
\hline External links lead to relevant and reputable resources & $\square$ \\
\hline Third party material is copyright cleared & $\square$ & $\square$ \\
\hline Additional notes and recommendations: & $\square$ \\
\hline
\end{tabular}

\section{2) Coursework and assessment}

\begin{tabular}{|l|cc|}
\hline Criteria & YES NO NA \\
\hline Assessment specifications and criteria are clear and explicit & $\square$ \\
\hline Periodic deadlines are in place to help ensure engagement & $\square$ \\
\hline $\begin{array}{l}\text { There is an appropriate mix of individual and collaborative pieces of } \\
\text { coursework }\end{array}$ & $\square$ \\
\hline $\begin{array}{l}\text { There are opportunities for periodic self-testing and/or suggested } \\
\text { self-reflective tasks and activities }\end{array}$ & $\square$ \\
\hline $\begin{array}{l}\text { The assessed work is likely to be well-supported by the range of } \\
\text { tools and resources provided online }\end{array}$ & $\square$ \\
\hline $\begin{array}{l}\text { The work to be undertaken is fikely to be engaging without } \\
\text { overioading students }\end{array}$ & $\square$ \\
\hline Additional notes and recommendations: & $\square$ \\
\hline
\end{tabular}


3) Communication and collaboration

\begin{tabular}{|l|c|}
\hline Criteria & YES NO \\
\hline Students are required to collaborate on key tasks & $\square$ \\
\hline $\begin{array}{l}\text { There is a means for students to ask general questions of the tutor } \\
\text { and each other (eg a problems forum) }\end{array}$ & $\square$ \\
\hline $\begin{array}{l}\text { There are opportunities to communicate synchronously (eg using a } \\
\text { chat tool) where this would be beneficial }\end{array}$ & $\square$ \\
\hline $\begin{array}{l}\text { Requirements for communicating and collaborating online are clearly } \\
\text { stated (eg where optional and not, guidelines) }\end{array}$ & $\square$ \\
\hline $\begin{array}{l}\text { Students are provided with appropriate online spaces to support } \\
\text { group work (eg private discussion areas, wikis) }\end{array}$ & $\square$ \\
\hline $\begin{array}{l}\text { There are online social spaces provided for non-assessed, informal } \\
\text { discussion and communication }\end{array}$ & $\square$ \\
\hline
\end{tabular}

Additional notes and recommendations:

\section{4) Student support}

\begin{tabular}{|c|c|c|}
\hline Criteria & YES & NO N/A \\
\hline $\begin{array}{l}\text { Students are provided with clear infomation about how to study } \\
\text { effectively in the context of this module, including how to make good } \\
\text { use of the online tools and resources }\end{array}$ & $\square$ & $\square$ \\
\hline Introductory icebreaking/bonding activities are in place & $\square$ & $\square$ \\
\hline $\begin{array}{l}\text { Just-in-time guidance (eg that reinforce task requirements or } \\
\text { provide useful study tips) is embedded at appropriate points in } \\
\text { subject materials and activity descriptors }\end{array}$ & $\square$ & $\square$ \\
\hline $\begin{array}{l}\text { What the student can expect from the tutor (eg in tems of response } \\
\text { rate, when they will be online) is clearly stated }\end{array}$ & $\square$ & $\square$ \\
\hline VLElother technical specifications are provided or linked to & $\square$ & $\square$ \\
\hline $\begin{array}{l}\text { Additional support features (eg glossary, calendar, announcements, } \\
\text { world clock) are provided where useful }\end{array}$ & $\square$ & $\square$ \\
\hline
\end{tabular}

Additional notes and recommendations:

5) Use of multimedia (visual and/or audio, static and/or interactive)

\begin{tabular}{|l|cc|}
\hline Criteria & YES NO N/A \\
\hline $\begin{array}{l}\text { Multimedia is used appropriately to present subject material and/or } \\
\text { to complement text-based explanations }\end{array}$ & $\square$ \\
\hline Multimedia elements are easy to use and interact with & $\square$ \\
\hline Additional notes and recommendations: & $\square$ \\
\hline
\end{tabular}

Evaluation of

Assessment

Method to

Incorporate

Graduate Attributes

in Building

Surveying Module 
Chowdhry, S. Garnier, C.

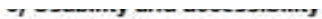

\begin{tabular}{|l|c|}
\hline Criteria & YES NO NA \\
\hline The online module environment is easy to navigate & $\square$ \\
\hline $\begin{array}{l}\text { Information-equivalent alternatives to static and interactive } \\
\text { multimedia content are provided }\end{array}$ & $\square$ \\
\hline Links to any browser plug-ins required are provided & $\square$ \\
\hline $\begin{array}{l}\text { Appropriate altemative means for navigating content (eg search, } \\
\text { site index, activities-view) are in place }\end{array}$ & $\square$ \\
\hline $\begin{array}{l}\text { Visual design is clear and non-distracting } \\
\text { Text is readable and presented in non-serif fonts }\end{array}$ & $\square$ \\
\hline $\begin{array}{l}\text { Links to external websites or content files open up in a new browser } \\
\text { window }\end{array}$ & $\square$ \\
\hline Additional notes and recommendations: & $\square$ \\
\hline
\end{tabular}

A note on programme level online provision

It is noted that guidance and materials might be more appropriately placed on the programme home rather than on the module site. Material there could include, but is not restricted to:

- Teaching team.

- Module descriptors.

- Programme level online problems forum.

- Programme level online induction activities and documentation.

- Links to Edinburgh Napier library. C\&IT, Student Affairs, SSCC (Student staff consultative committee), class representatives, plagiarism website.

- General study skills advice.

- Technical guides.

7) Final comments and recommendations

Please use the space below to make any final comments you have and include any changes you would recommend be made to the module prior to its implementation.

Signed:

Date reviewed: 


\section{APPENDIX III - PROPOSED "STUDENT ACTIVITY" AND "AS- SESSMENT" SECTIONS}

Considering the proposed new assessment scheme the student activity and the module assessment should be as follow:

Table 14: Student Activity

\begin{tabular}{|l|l|l|}
\hline Mode of activity & L\&T activity & NESH \\
\hline Face-to-Face & Lecture & 24 \\
\hline Face-to-Face & Tutorial/Seminars/Group work & 24 \\
\hline Assessment & Exam, Presentation & 4 \\
\hline Online & Reflection activities & 30 \\
\hline Individual learning activities & Group work & 118 \\
\hline TOTAL NESH & & $=\mathbf{2 0 0}$ hours \\
\hline
\end{tabular}

Table 15: Assessment

\begin{tabular}{|l|l|l|l|l|}
\hline Week & Type of assessment & Weighting & $\begin{array}{l}\text { LOs } \\
\text { covered }\end{array}$ & Length/ volume \\
\hline $\begin{array}{l}\text { One } \\
\text { Enter assessment ele- } \\
\text { ment(s): }\end{array}$ & $\begin{array}{l}\text { Group display poster \& oral } \\
\text { presentation }\end{array}$ & $25 \%$ & $3,4,5$ & 15 min \\
\hline 8,9 & $\begin{array}{l}\text { Self and Peer Assessment } \\
\text { Onssessment }\end{array}$ & $10 \%$ & $\begin{array}{l}\text { To be } \\
\text { addressed }\end{array}$ & $\begin{array}{l}1 \text { A4 page of } \\
\text { standards and } \\
\text { criteria }\end{array}$ \\
\hline 12 & $\begin{array}{l}\text { Interactive online discussion } \\
\text { participation }\end{array}$ & $5 \%$ & $1-6$ & $\begin{array}{l}100 \text { words per } \\
\text { discussion }\end{array}$ \\
\hline & Component subtotal: & $40 \%$ & $1-6$ & 3 hrs \\
\hline Component: Assessment Two & & $60 \%$ & & \\
\hline Enter assessment element(s): & Centrally timetabled exam & $60 \%$ & & \\
\hline $14 / 15$ & Component subtotal: & $60 \%$ & & \\
\hline & Module total: & $100 \%$ & & \\
\hline
\end{tabular}

